\title{
"A Divine Infection": A Systematic Review on the Roles of Religious Communities During the Early Stage of COVID-19
}

\author{
Mikyung Lee ${ }^{1} \cdot$ Heejun $\operatorname{Lim}^{1} \cdot$ Merin Shobhana Xavier ${ }^{2,3} \cdot$ Eun-Young Lee ${ }^{1,3} \mathbb{D}$
}

Accepted: 20 July 2021 / Published online: 17 August 2021

(C) The Author(s), under exclusive licence to Springer Science+Business Media, LLC, part of Springer Nature 2021

\begin{abstract}
The objective of this systematic review was to summarize the roles that religious communities played during the early stage of COVID-19 pandemic. Seven databases were searched and a total of 58 articles in English published between February 2020 and July 2020 were included in evidence synthesis. The findings of the literature showed diverse influences of religion as a double-edged sword in the context of COVID-19 pandemic. Religious communities have played detrimental and/ or beneficial roles as a response to COVID-19 pandemic. A collaborative approach among religious communities, health science, and government is critical to combat COVID-19 crisis and future pandemics/epidemics.
\end{abstract}

Keywords Coronavirus SARS-CoV-2 · Pandemic · Social determinants of health · Faith communities

\section{Introduction}

COVID-19 is rapidly spreading worldwide, and one of the main avenues that have contributed to outbreaks and community transmissions is religion, particularly religious communities and their spaces, and religious beliefs/disbeliefs of COVID-19 itself. Religion is "[...] a complex of culturally prescribed practices" that depend on "supernatural powers." Religion often serves as a basis for social organizations, such as communities and institutional spaces, that may involve the performance of

Eun-Young Lee

eunyoung.lee@queensu.ca

1 School of Kinesiology and Health Studies, Queen's University, KHS 307, 28 Division St, Kingston, ON K7L 3N6, Canada

2 School of Religion, Queen's University, Kingston, ON, Canada

3 Department of Gender Studies, Queen's University, Kingston, ON, Canada 
individual and collective ritual practices, beliefs, and actions (Smith, 2019, p.22). As a social determinant of health, religion largely shapes public health issues such as epidemics and pandemics (Idler, 2014). Indeed, religion and infectious diseases have historically been deeply entangled (Idler, 2014). In the history of epidemics, in particular, religious communities have played an intimate role in shaping collective beliefs or theological systems which inform responses to health crises. Some religious practices and rituals have also been known to pose a risk for infection and have put people within the religious communities particularly at risk of contracting infectious diseases.

As witnessed thus far with COVID-19 pandemic, religious spaces (e.g., churches and mosques) and rituals (e.g., pilgrimages and funerals) have been drastically altered or halted due to restrictions imposed on any social gatherings. Concurrently, some religious communities, particularly those with a tendency to be politically conservative (e.g., evangelical Christians), have defied government-suggested quarantine rules. Some religious communities also have continued to hold large services, which have gone on to further increase the spread of COVID-19 among those in the community and beyond. In such instances, religion is positioned against the virus, and broadly science, as a deceptive evil from which true faith and trust in God will protect (or spiritually vaccinate) true believers. Such trends have been noted in South Korea, Trinidad, the USA, and other countries (Quadri, 2020; Wildman et al., 2020). The latter instance raises questions of religious freedom and liberties, which are tied to rights discourses in neoliberal secular states. Furthermore, the impact of COVID-19 on one's physical, mental, social, and emotional health can be more harmful when one's religious identity or belonging intersects with other marginalized identities (e.g., women, people of color, socioeconomic status).

Religion has played a significant role in public health crises, such as with the spread and mitigation of HIV/AIDS and other infectious diseases (Blevins et al., 2019; Idler, 2014; Pugh, 2010). However, the complex dynamics between religion and infectious diseases has been largely overlooked and understudied (Kawachi, 2020; Ransome, 2020), especially within an interdisciplinary framework. In this context, more research on clarifying the association between health and religion as an important social determinant of health is needed to provide a deeper understanding of religion's role in individual and community health (Kawachi, 2020; Ransome, 2020). As we are currently living in the COVID-19 era, addressing the role of religion in the context of COVID-19 is timely and necessary (Carey, 2020; Hart \& Koenig, 2020). Therefore, the objective of this systematic review was to summarize the roles religious communities play in the transmission, mitigation, and/or adaptation during the early stage of COVID-19 pandemic (from December 2019 to July 2020).

\section{Methods}

This study used a systematic review study design to summarize the literature. Systematic review is a structured literature review that provides a comprehensive synthesis of data that are extracted from relevant studies. It is beneficial for readers 
who want to look at objective and unbiased data for a certain research question in each article selected for the review (Aromataris \& Pearson, 2014). Reporting guidelines from the Preferred Reporting Items for Systematic Reviews and Meta-Analyses (PRISMA) were used to describe the process of conducting a systematic review and results of the review as transparent as possible (Page et al., 2021). The review protocol was also registered on the international prospective register of systematic reviews, PROSPERO, at the beginning of the review process for transparency (https://www.crd.york.ac.uk/prospero/display_record.php?RecordID=182884).

\section{Eligibility Criteria}

There were no restrictions on the types of study design eligible for inclusion. Quantitative and qualitative studies, commentaries, editorials, and news articles were all included. Specific inclusion criteria included the following: (1) all human population of any age in any country; (2) both peer-reviewed and grey literature published in English; (3) empirical studies that report the epidemiological evidence of transmission, mitigation, and/or adaptation of COVID-19 due to religious communities, institutions, ritual practices and/or activities; and (4) analyses that discuss COVID19 in relation to religious practices or activities. Exposures that were considered to be eligible were practices and activities related to religious communities, New Religious Movements (or cults), and/or theology inclusively.

Articles were excluded if they were thesis dissertations, pharmacological or biochemical studies. The indiscriminate nature of the eligibility criteria was due to the concurrent and evolving nature of the pandemic. The primary outcomes prioritized in this study were the incidence, outbreak, spread, and mitigation of COVID-19, inclusively and the role of religion in this process.

\section{Information Sources and Search Strategy}

The following seven electronic databases were used for literature searches in English: ATLA Religion, BioRxiv, CINAHL, LitCOVID, MEDLINE, PsycINFO, and Web of Science. A manual search of the reference lists of included papers was also completed to investigate whether any further relevant papers have been missed. Searches were limited to English language articles, peer-reviewed, refereed publication and grey literature, and studies on human. There were no search limitations regarding the year of publication; however, the start date was set at December 01, 2019. The initial searches were conducted on June 1, 2020, and top-up searches were followed on July 22, 2020, to capture all available up-to-date evidence. Keywords that were used for searches in each database are described in Appendix 1.

\section{Study Selection}

The primary investigator (EL) developed a search protocol and used Covidence (www.covidence.org) to manage references and remove duplicates. Article screening for title/abstract (Level 1) and full text (Level 2) was done by two independent 
reviewers. In cases where a decision for exclusion or potential inclusion cannot be made by the title/abstract, the full text was retrieved. After completing the Level 1 screening, full text of the included articles was retrieved and further screened based on inclusion and exclusion criteria. Two reviewers independently read full text of the articles to verify eligibility and complete inclusion/exclusion checklists. During the screening process, any disagreements were resolved through a consensus discussion, and if consensus cannot be reached, the final inclusion of articles was then decided by a third reviewer. Inter-rater reliability between two reviewers was Cohen's $\kappa=$ 0.77 (substantial agreement) at Level 1 and Cohen's $\kappa=0.61$ (substantial agreement) at Level 2.

\section{Data Collection Process and Data Items}

Data extraction was completed using the Excel sheet to gather relevant information from included studies by two reviewers. The data extracted from all relevant studies included: bibliographic information of studies (i.e., authors and year of publication); study design (e.g., quantitative, qualitative, correspondence, editorial, research letter); research location; exposure and outcome measurements (if available); and the results reported. One researcher extracted data from all included studies then reviewed by another researcher. Discrepancies were resolved through consensus discussion. The relationships between religion and transmission, mitigation, and/or adaptation of COVID-19 indicated in each article were extracted.

\section{Summary of Measures and Synthesis of Results}

The summary of findings included design, country (geographical location), population, sample size (if available), analytic method, reported outcomes of interest, reported relationships between religion and COVID-19, and relevant inferential statistical results, if available. Conclusions of included opinion literature were grouped into statements that comment on relationships between religion and COVID-19 outcomes, and statements that make explicit policy recommendations for mitigating COVID-19 pandemic. Findings were summarized narratively in terms of the role religion has played and their implications for the decisions of governments and health care organizations in responding to COVID-19 pandemic.

\section{Results}

\section{Study Selection}

The number of studies that was included in the title/abstract screening and full text screening by language are provided in the PRISMA flowchart for study selection (Fig. 1). After removing duplicates, 542 articles were found during the initial search on June 3, 2020, then 297 more articles during the top-up search on July 23, 2020. A total of 839 articles were screened for title/abstract. Of these, 728 articles were 


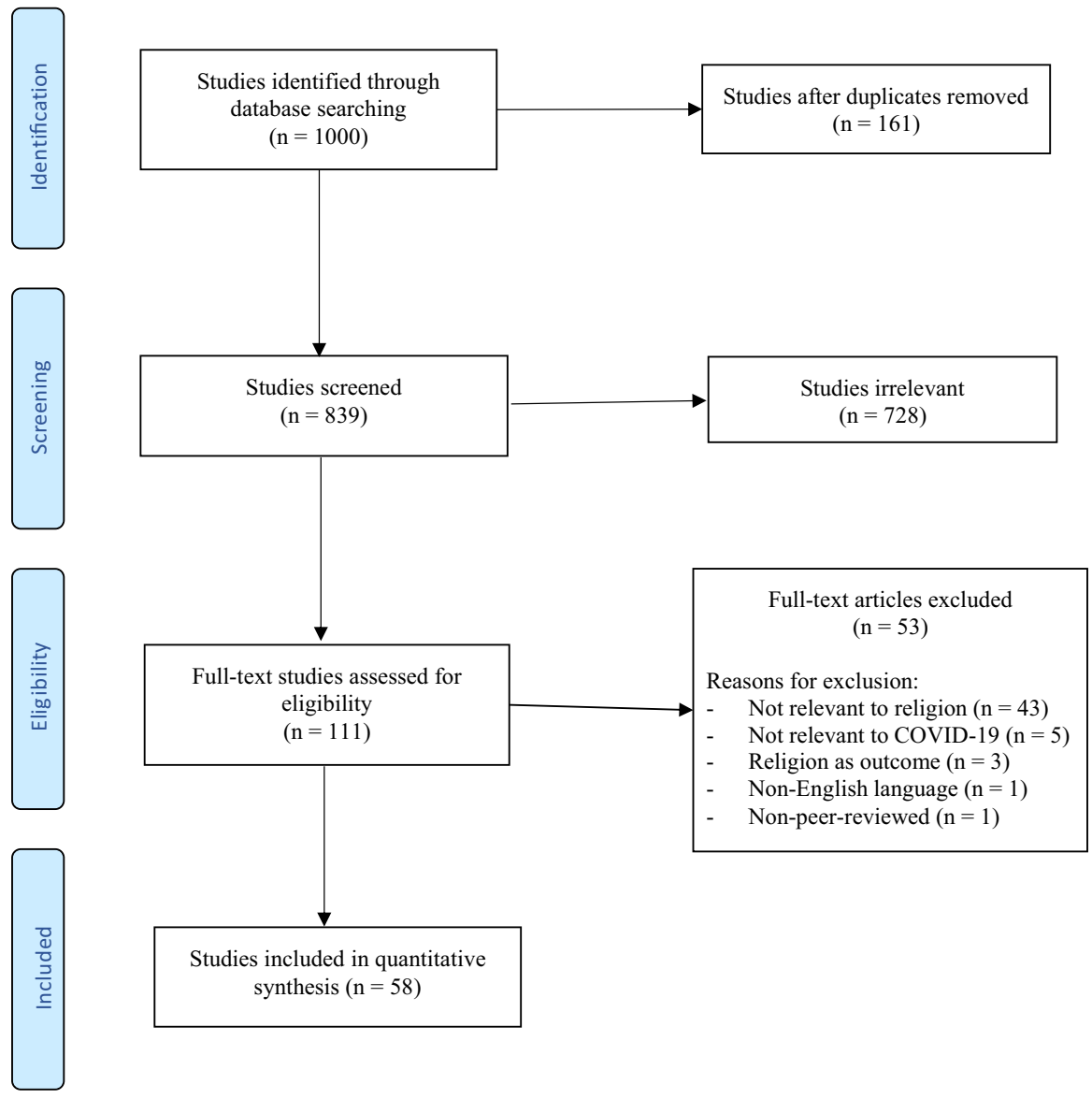

Fig. 1 PRISMA flow chart for systematic searches

excluded based on the eligibility criteria, leaving a total of 111 articles for full text screening. After removing 53 irrelevant articles, 58 articles in English were included in this review.

\section{Characteristics and Epidemiological Statistics of Included Articles}

As outlined in Fig. 2 which illustrates descriptive characteristics of the included articles, the most common study type among included articles was commentary $(n=12)$ followed by the cross-sectional design $(n=8)$. As for religious groups of interest, Islam was mentioned most frequently $(n=29)$, followed by Christianity $(n=12)$. In addition, mitigation $(n=26)$ was the most addressed role of religion in response to COVID-19, followed by adaptation $(n=20)$ and transmission $(n=18)$.

In terms of epidemiological statistics, nine studies reported epidemiological statistics regarding COVID-19 in Middle East $(n=3)$ (Al-Rousan \& Al-Najjar, 2020; 


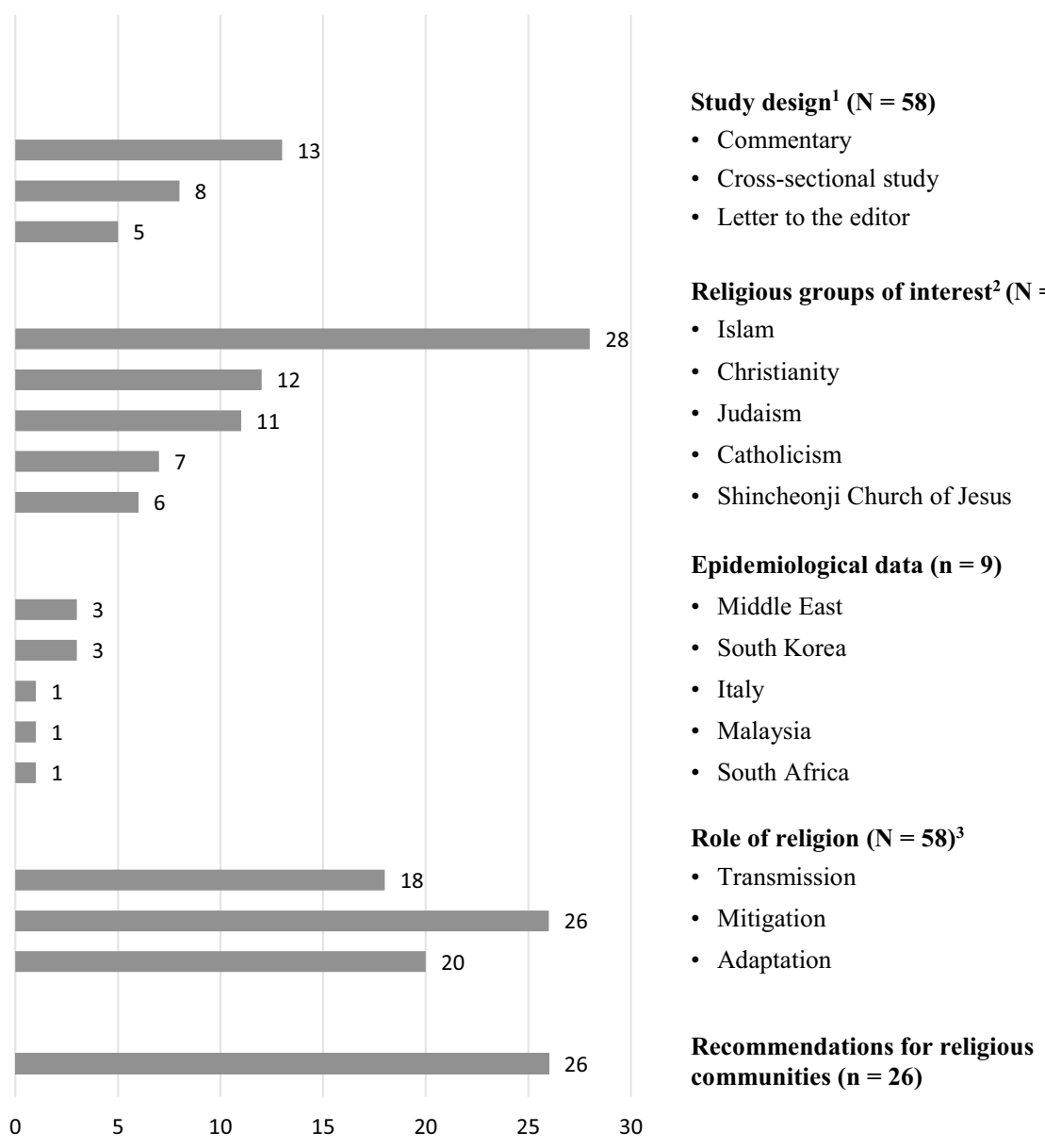

Fig. 2 Descriptive characteristics of the articles included $(\mathbf{N}=\mathbf{5 8}) .{ }^{1}$ Other study designs included Letter $(n=3)$, Editorial $(n=3)$, Perspective $(n=3)$, Short communication $(n=1)$, Special section article $(n=2)$, Rapid communication $(n=2)$, Impressionistic reporting $(n=2)$, Original paper $(n=2)$, Correspondence $(n=2)$, Retrospective analytic epidemiology $(n=1)$, Case study $(n=1)$, Community trial $(n=1)$, Psychological exploration $(n=1)$, Brief report $(n=1)$, Observational study $(n=1)$, Preliminary report $(n=1)$, Philosophical exploration $(n=1)$, Opinion $(n=1)$, Review $(n=1)$, Qualitative study $(n=1)$, Policy recommendation $(n=1)$, Unsure $(n=1) .{ }^{2}$ Other religion included Hinduism $(n=5)$, Buddhism $(n=4)$, Maronite $(n=2)$, Neo-Pentecostal Churches $(n=1)$, Afro-Brazilian Candomblé $(n=1)$, Umbanda $(n=1)$, Shinto $(n=1)$, New religions $(n=1) .{ }^{3}$ Eight out of 58 included articles addressed $\geq$ one role that religion plays during the early stage of the COVID-19 pandemic

Atique \& Itumalla, 2020; Yezli \& Khan, 2020b), South Korea $(n=3)$ (Choi et al., 2020; Ha, 2020; Kang, 2020), Italy $(n=1)$ (Chirico \& Nucera, 2020), Malaysia $(n=1)$ (Mat et al., 2020), and South Africa $(n=1)(J a j a$ et al., 2020).

The epidemiological statistics reported in the Middle East were addressed between countries, rather than in one country, regarding international pilgrimage practice as a main topic. Atique and Itumalla (2020) showed the COVID-19 cases 
transmitted between the Kingdom of Saudi Arabia and Bahrain, indicating the confirmed case of 2,795 that were related to religious ritual traveling as of April 2020 (Atique \& Itumalla, 2020). Al-Rousan and Al-Najjar (2020) reported the COVID19 cases transmitted between Iran and Israel through Jewish pilgrimages whereby 6 confirmed cases in the beginning of March became 193 cases by March 15, 2020 (Al-Rousan \& Al-Najjar, 2020).

The epidemiological statistics reported in South Korea were primarily addressed the first "super-spreader," known as "patient 31," who transmitted COVID-19 to many people among the Sincheonji religious group. The severity of large religious gatherings was also highlighted with statistics showing that approximately $60 \%$ of the confirmed cases nationwide were linked to Sincheonji religious group as of March 2020 (Choi et al., 2020; Kang, 2020; Kim et al., 2020). The statistics reported in Malaysia also revealed the severe impact of mass religious gatherings, of which more than $35 \%$ of COVID-19 cases were related to the mass Sri Petaling Muslim missionary gathering between February 27, 2020, and March 1, 2020 (Mat et al., 2020). In Italy, it was reported that 60 priests have died in March 2020 (Chirico \& Nucera, 2020). The statistics reported in South Africa indicated that 80 people tested positive for COVID-19 after a single religious event which led to 1,600 potential cases among those who attended the event (Jaja et al., 2020). The detailed descriptive characteristics and epidemiological reporting of the included articles are displayed in Appendix 2.

\section{Findings on Transmission}

A total of 18 studies (Agley, 2020; Ali \& Alharbi, 2020; Al-Rousan \& Al-Najjar, 2020; Alzoubi et al., 2020; Atique \& Itumalla, 2020; Capponi, 2020; Choi et al., 2020; Chukwuorji \& Iorfa, 2020; Freeman et al., 2020; Hill et al., 2020; Jaja et al., 2020; Kang, 2020; Kim et al., 2020; Lan et al., 2020; Lorea, 2020; Mat et al., 2020; Shah et al., 2020; Wildman et al., 2020) have addressed religion as a cause for transmission, of which religious gatherings and practices contributed to the outbreak and spread of COVID-19. COVID-19 was predominantly spread through religious gatherings without adhering to the physical distancing recommendation. These types of gatherings included rituals (e.g., pilgrimages and funerals) and travelling to shrines (e.g., a monument to Mary, mother of Jesus and Kaaba).

Religious institutions or communities were identified as spaces where misinformation about the infection proliferated which further cultivated mistrust towards science and health care directives among religious adherents of these communities (Appendix 3). Specifically, studies mainly discussed how religious gatherings spread COVID-19 and the negative association between religiosity and trust in science and public health guidelines (Agley, 2020; Ali \& Alharbi, 2020; Al-Rousan \& Al-Najjar, 2020; Alzoubi et al., 2020; Atique \& Itumalla, 2020; Capponi, 2020; Choi et al., 2020; Chukwuorji \& Iorfa, 2020; Freeman et al., 2020; Hill et al., 2020; Jaja et al., 2020; Kang, 2020; Kim et al., 2020; Lan et al., 2020; Lorea, 2020; Mat et al., 2020; Shah et al., 2020; Wildman et al., 2020). 
With respect to the association between religiosity and trust in science, and public health guidelines, Agley (2020) indicated that a higher score in religious commitment was associated with lower overall trust in science (Agley, 2020). Furthermore, Hill and colleagues (2020) demonstrated that more religious states in the USA tended to show a higher average mobility score and more public resistant to public health recommendations (Hill et al., 2020). Similarly, a study that explored the relationship between religiosity and beliefs in the COVID-19 conspiracy showed that general COVID-19 conspiracy beliefs were positively associated with a higher level of religiosity (Freeman et al., 2020).

In summary, transmission (e.g., outbreak, spread) of COVID-19 has been enacted mainly through religious gatherings and practices. Furthermore, proliferated misinformation on COVID-19 within religious communities and mistrust based on misinformation were attributable to COVID-19 transmission.

\section{Findings on Mitigation}

Twenty-six studies reported on the mitigating role of religion during the early stage of COVID-19 (Ahmed \& Memish, 2020; Al-Rousan \& Al-Najjar, 2020; Ali \& Alharbi, 2020; Atique \& Itumalla, 2020; Crubézy \& Telmon, 2020; Ebrahim \& Memish, 2020a, 2020b; Escher, 2020; Frei-Landau, 2020; Gautret et al., 2020; Ha, 2020; Hong \& Handal, 2020; Iqbal et al., 2020; Kim et al., 2020; McCloskey, et al., 2020a, 2020b; Memish et al., 2020; Muurlink \& Taylor-Robinson, 2020; Quadri, 2020; Tarimo \& Wu, 2020; Waitzberg et al., 2020; Weinberger-Litman et al., 2020; Wildman et al., 2020; Wong et al., 2020; Yezli \& Khan, 2020a, 2020b) (Appendix 3).

These articles mainly discussed an urgent need to cancel rïeligious gatherings and events to mitigate the transmission and outbreak of COVID-19, even though they can be understood as a significant opportunity for its believers. These articles also highlighted the importance of institutional and intersectoral collaborative work among science, religion, and government to prevent and control the spread of COVID-19 (Hashmi et al., 2020; Hong \& Handal, 2020). It was also reported that several countries (e.g., South Korea and Italy) have enacted national laws that ban religious gatherings and mandated testing and quarantining of suspected individuals with COVID-19 to prevent further spread of the virus (Chirico \& Nucera, 2020; Kim et al., 2020).

In summary, cancelling religious gatherings and events was discussed as a main COVID-19 mitigation strategy that various religious communities have already implemented. Furthermore, collaborative work with science and government was addressed as a potential mitigation strategy.

\section{Findings on Adaptation}

Adaptation as a role of religion during the early stage of COVID-19 was addressed in 20 articles (Chirico \& Nucera, 2020; Frei-Landau, 2020; Galiatsatos et al., 2020; Greene et al., 2020; Hashmi et al., 2020; Hong \& Handal, 2020; Koenig, 2020a, 2020b; Lee, 2020; Lee et al., 2020; Levin, 2020; Modell \& Kardia, 2020; Nahandi 
et al., 2020; Peteet, 2020; Prime et al., 2020; Thompkins et al., 2020; Tootee \& Larijani, 2020; Umucu \& Lee, 2020; Waitzberg et al., 2020; Waqar \& Ghouri, 2020) (Appendix 3). These articles primarily addressed new ways of performing religious practices (e.g., online gatherings, broadcasting religious ceremonies) and religious leaders and communities' appropriate response to COVID-19 and positive coping strategies (Koenig, 2020a, 2020b; Peteet, 2020; Umucu \& Lee, 2020). Conversely, two studies explored negative religious outlooks where believers wondered whether they were abandoned by God at the time of COVID-19 (Lee, 2020; Lee et al., 2020). Supporting religious leaders and religious medical professionals who are suffering from psychological stressors during COVID-19 was also discussed in two studies (Greene et al., 2020; Nahandi et al., 2020).

In summary, studies have highlighted that religious practices and events now must be conducted in a way that is considered a "new normal" (e.g., online gatherings, broadcasting religious ceremonies).

\section{Roles of Religion Summary}

Out of 58 articles that were included in this review, eight articles addressed more than one role that religion has played during the early stage of COVID-19 (AlRousan \& Al-Najjar, 2020; Atique \& Itumalla, 2020; Frei-Landau, 2020; Hill et al., 2020; Hong \& Handal, 2020; Kim et al., 2020; Waitzberg et al., 2020; Wildman et al., 2020) while two articles did not indicate any role but reported epidemiological evidence in relation to religious communities (McLaughlin, 2020; Safdar \& Yasmin, 2020) (Appendix 3).

Out of 64 observations in 54 articles of which varying roles of religion were addressed, $28.1 \%(n=18)$ were related to the detrimental role of religion such as outbreaks of COVID-19 through religious gatherings as well as mistrust/misinformation towards science and public health guidelines among religious groups. More importantly, most articles $(71.9 \%$; $n=46)$ have addressed the beneficial roles of religion where different religious communities have contributed to mitigating the infection and adapting safe approaches to organize religious practices. Various roles of religion during the early stage of COVID-19 are summarized in Fig. 3.

\section{Policy Recommendations}

Findings on policy recommendations for religious groups to combat COVID-19 are summarized in Table 1. A total of 26 articles provided recommendations on controlling and managing COVID-19 (Ahmed \& Memish, 2020; Al-Rousan \& Al-Najjar, 2020; Atique \& Itumalla, 2020; Chirico \& Nucera, 2020; Crubézy \& Telmon, 2020; Ebrahim \& Memish, 2020a, 2020b; Escher, 2020; Gautret et al., 2020; Greene et al., 2020; Ha, 2020; Hashmi et al., 2020; Hong \& Handal, 2020; Iqbal et al., 2020; Jaja et al., 2020; Kang, 2020; Koenig, 2020b; Mat et al., 2020; McCloskey, et al., 2020b; Memish et al., 2020; Quadri, 2020; Tarimo \& Wu, 2020; Thompkins et al., 2020; Wong et al., 2020; Yezli \& Khan, 2020a, 2020b). 


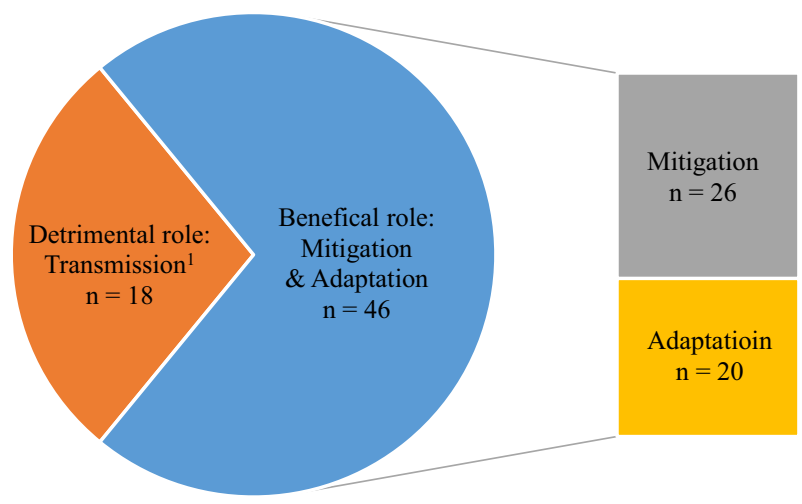

Fig. 3 Beneficial (mitigation \& adaptation) and detrimental roles (transmission) of religion during the early stage of the COVID-19 pandemic discussed in the included articles $(n=56) .{ }^{1}$ Transmission included outbreak and spread of COVID-19 and mistrust/misinformation towards science and public heath guidelines. Note: A total of 64 observations were made from 56 articles

The majority of the articles unanimously recommended that religious events and rituals should be suspended or cancelled to contribute to the safety of communities (Ahmed \& Memish, 2020; Atique \& Itumalla, 2020; Crubézy \& Telmon, 2020; Ebrahim \& Memish, 2020a, 2020b; Kang, 2020; Mat et al., 2020; McCloskey, et al., 2020a; Memish et al., 2020; Quadri, 2020; Tarimo \& Wu, 2020; Yezli $\&$ Khan, 2020a). Similarly, three articles suggested to promote religious gatherings and rituals in accordance with newly implemented travel restrictions (Al-Rousan \& Al-Najjar, 2020; Gautret et al., 2020; Jaja et al., 2020). Furthermore, two articles specifically recommended and addressed the importance of a collaborative approach among religious communities, science, healthcare providers, and policymakers (Hashmi et al., 2020; Hong \& Handal, 2020).

All in all, policy recommendations in response to COVID-19 were in line with the mitigation and adaptation roles of religion found in this review, of which primarily included cancelling religious gatherings and events to mitigate transmission and collaborating with science and government to develop effective strategies for both mitigation and adaptation to COVID-19 and subsequent lockdowns and restrictions.

\section{Discussion}

\section{Roles of Religion During the Early Stage of COVID-19}

This was the first systematic review summarizing the role of religious communities in the transmission, mitigation, and adaptation during the early stage of COVID19 pandemic. There is no doubt that several religious gatherings and practices have accelerated the transmission of the COVID-19 virus and endangered people around the world. Having said that, religion has played an important role in mitigating the infection and its impacts as well as helping people to cope with trauma 
Table 1 Practical recommendations to control and manage COVID-19 $(n=26)$

Author and publication year

Ahmed and Memish (2020)

Al-Rousan and Al-Najjar (2020)

Atique and Itumalla (2020)

Chirico and Nucera (2020)

Crubézy and Telmon (2020)

Ebrahim and Memish (2020a)

Ebrahim and Memish (2020b)

Escher (2020)

Gautret et al. (2020)

Gautret et al. (2020)

Ha (2020)
Recommendations to control and manage COVID-19

The authors recommended Hajj to be cancelled; "KSA in canceling Hajj 2020 well in advance of the events would be very much in line with Islamic ideals and would contribute greatly to the safety of humanity" (p. 2)

As visiting Qom and other shrines in Iran is the main transmission route for CoVID-19 in the Gulf countries, "this study thus suggests closure of borders between Gulf countries, Lebanon and Iran" (p. 5817)

"We urge the Ministry of Hajj and Umrah, and with the assistance of leading religious scholars, should investigate the potential issues related to Hajj and propose feasible solutions to contain the prevailing situation. The Saudi government should seriously consider the option of a complete lockdown in the country until the pandemic is under control" [...] "the government may focus on awareness drive among people, including social media" (p. 2)

"[...] spiritual skills should be recognized as "core" skills for healthcare professionals and be implemented in all medical curricula" (no page number available)

The authors' recommendations for funerary rituals: "Jewish religion the "tahara", the rite of purification of the body of the deceased, must be prohibited; no embalming; for Muslim religion, the Tayammum (dry toilet by placing both hands on a stone or earth) may be sufficient" (p. 22)

The authors recommended Umrah to be cancelled and "KSA (Kingdom of Saudi Arabia) also has to manage diplomatic challenges with large pilgrim volume countries and manage requests for exemptions" (p. 2)

"Cancellation of suspension of mass gatherings be critical to pandemic mitigation" including Hajj based on the past experiences with respiratory diseases (p. 2). "Institutions with the mandates for outbreak monitoring and response should keep an inventory of mass gatherings and provide advance warnings and recommendations about outbreaks to the organizer including information on event cancellation, crowd size limitations, or alternatives" (p. 3)

The author recommended to follow the existing WHO mass gathering guidelines and "educate its population on best practices for infection control: consistent hand hygiene, social distancing, respiratory hygiene, testing and the use of quarantine" (p. 3)

The authors recommended "If travel restrictions are successful in avoiding the extension of the outbreak to the Kingdom of Saudi Arabia in the following months, authorities may have to restrict temporarily the entry of pilgrims from affected countries into KSA" (p. 1)

Recommendations to religious leaders who has affected by moral injury: "(1) self-care; (2) spirituality; (3) acknowledge moral conflicts; (4) purpose; (5) supervision and peer support; (6) social support; and (7) professional support." (p. 2)

"Religious organizations should maintain bipartisanship with science by prohibiting close proximity among believers" (p. 2) 
Table 1 (continued)

Author and publication year

Hashmi et al. (2020)

Hong and Handal (2020)

Iqbal et al. (2020)

Jaja et al. (2020)

Kang (2020)

Koenig (2020a, 2020b)

Mat et al. (2020)

McCloskey et al. (2020a, 2020b)

Memish et al. (2020)

Quadri (2020)

Tarimo and $\mathrm{Wu}(2020)$
Recommendations to control and manage COVID-19

The authors proposed "a collaborative model between religious communities and healthcare providers/policymakers to manage the COVID-19". (p. 2)

The author recommended for science, religion, and government to work together "to cope with this worldwide pandemic" as "pitting religious truth against scientific truth is only a path to failure". (p. 5)

The author argued that "One possible solution to this religious cliché is to engage the religious leaders of the respective societies.". (p. 278)

The author recommended that "Religious and cultural activities of any form must be restricted at this time. [...] The government must intensify the enforcement of lockdown measure and promptly identify miscreants with dubious travel permit documents and those who travel with empty caskets to evade police arrest". (p. 1078)

"When a new infectious disease is spreading, the government should sharply curtail group gatherings and religious events." (p. 170)

The author made seven recommendations to help older adults to protect themselves and cope with difficulties during the COVID-19 pandemic: "(1) spend time developing a deeper religious faith; (2) stay physically healthy (e.g., to care for the "temple of Holy Spirit" follow by the Christian tradition); (3) care for your neighbour emphasized by Jesus, Moses, theProphet Muhammad, the Buddha, Hindu sages, and other greater religious figures); (4) care for neighbour by meeting emotional needs; (5) care for neighbour by meeting physical needs; (6) follow by social distancing guidelines; and (7) taking advantage of technology (e.g., social and spiritual hugs and handshakes)" (p. 1-3)

The authors recommended that "mass gatherings, be it for religious or other purposes, should be cancelled and banned throughout the period of the COVID pandemic." (p. 4)

Even though a precautionary approach is often used to explain MG cancellations, "events should be cancelled or postponed on the basis of a context-specific risk assessment" as "these cancellations have social and economic impact on public morale, on national economies and on individual livelihoods." (p. 1098)

The author argued that "premature promotion of mass gatherings can only lead to re-ignition of the pandemic." (p. 1192). Therefore, the author recommended that "mass gatherings must be suspended." (p. 1191)

The author argued that "prompt responses such as suspension of communal gatherings must be promulgated to ensure social distancing." (p. 220)

"This letter calls upon the government of Tanzania to immediately suspend not only schools and colleges as it has been successfully done but also all religious and any other social gatherings." (p. 2) 
Table 1 (continued)

\begin{tabular}{|c|c|}
\hline Author and publication year & Recommendations to control and manage COVID-19 \\
\hline Thompkins et al. (2020) & $\begin{array}{l}\text { The authors argued that "the ultimate decision in this regard } \\
\text { would be made by each individual person (according to the } \\
\text { fatwas) based on the recommendations of the physician in } \\
\text { charge." (p. 3) }\end{array}$ \\
\hline Wong et al. (2020) & $\begin{array}{l}\text { The authors recommended for the "widespread testing at mass } \\
\text { gatherings in areas of known community transmission." (p. 2) }\end{array}$ \\
\hline Yezli and Khan (2020a) & $\begin{array}{l}\text { "We believe, for the time being, temporary closure of places } \\
\text { of worship for group prayers and religious services should } \\
\text { be implemented by countries around the word (especially } \\
\text { those with local COVID-19 transmission) regardless of faiths } \\
\text { involved, with alternatives offered if possible, to help fight the } \\
\text { pandemic." [...] "for such measures to be effective and not } \\
\text { be counterproductive, risk communication and educating the } \\
\text { public regarding the reasoning behind and aim of such actions } \\
\text { are crucial." (p. 1) }\end{array}$ \\
\hline Yezli and Khan (2020b) & $\begin{array}{l}\text { The author highlighted that despite the current suspension or } \\
\text { cancellation of religious mass gatherings such as the Umrah, } \\
\text { "further bold and probably unpopular measures are likely to be } \\
\text { introduced in the future" which include } 2020 \text { Hajj (p. } 1 \text { ) }\end{array}$ \\
\hline
\end{tabular}

during COVID-19 crisis. According to previous studies, religious beliefs and practices can positively influence individuals' psychological well-being by helping them relieve psychological stress and cope with trauma not only during COVID-19 but also during many other unprecedented times such as pandemic and/or disasters (e.g., terrorists attacks) (Blevins et al., 2019; Peteet, 2020; Pugh, 2010; Schuster et al., 2001; Umucu \& Lee, 2020).

Religion has acted as an important platform for intersectoral collaboration with science and government to combat COVID-19 as shown in the findings of our review on mitigation and adaptation. During the early stage of COVID-19, various religious institutions have collaborated with science sector and government authorities to innovate new measures of continuing religious commitments and rituals through social networks, TV channels, or live streaming (Capponi, 2020; FreiLandau, 2020). These new innovative measures following public health information have been effectively implemented by religious leaders as some religious believers tend to have more faith in religious leaders than science or public health guidelines (Kim et al., 2020; Quadri, 2020; Weinberger-Litman et al., 2020). This clearly demonstrates how powerful religious leaders can be in delivering public health messages and highlights the importance of collaborating with religious sectors when facing public health crises.

All in all, despite the harmful impacts on COVID-19 by certain religious groups, religious communities have been serving as a critical source for managing and controlling COVID-19 in multiple regions of the world while taking collaborative approaches with other sectors. 


\section{COVID-19, Religion, and Vaccine Hesitancy}

In December 2020, the first COVID-19 vaccine, Pfizer, rolled out, mainly in high income countries, which gave the global population hope that the pandemic will finally be under control, given that vaccine is considered the most promising strategy for eradicating the pandemic (Fisher et al., 2020). However, vaccine hesitancy which is defined as a "delay in acceptance or refusal of vaccination despite availability of vaccination services" (MacDonald et al., 2015, p. 4163) has been reported around the world and served as a main challenge in achieving community immunity. Historically, vaccination has been challenged for religious, scientific, and political reasons (Larson et al., 2014) and COVID-19 vaccination rollout has not been an exception.

Vaccine hesitancy due to religious reasons (e.g., false claims around religious permissibility of the vaccine or "infidel vaccine") is prevalent. According to a crosssectional study on COVID-19 vaccine acceptance with 2,058 Chinese respondents in March 2020 (Wang et al., 2020), 52.2\% of respondents reported that they would be willing to get vaccinated as soon as the vaccine is available while the remainder would delay the vaccination until the safety of the vaccination is verified and confirmed. A similar survey was conducted among 991 U.S. adults in April 2020 and showed that $57.6 \%$ of participants would be willing to take the COVID-19 vaccine, while the remaining $42.4 \%$ of the respondents reported that they were either not sure about getting vaccinated $(31.6 \%)$ or had no intention to be vaccinated (10.8\%) (Fisher et al., 2020). Compared to the surveys which have been conducted in the U.S. and China, survey results in Saudi Arabia represented a slightly higher percentage of vaccine hesitancy where more than half of the survey respondents $(55.3 \%, 1,715$ out of 3,101$)$ were hesitant to accept the COVID-19 vaccination (Magadmi \& Kamel, 2020).

One of the potential solutions to vaccine hesitancy is involving religious authorities in health awareness and vaccine promotion as they tend to have a powerful voice to their religious believers (Kim et al., 2020; Quadri, 2020; Weinberger-Litman et al., 2020). For example, in December 2020, The British Board of Scholars and Imams, a national board of Muslim, and other professional scholars made a statement that the COVID-19 vaccine is religiously permissible even though it contains haram ingredients or gelatine that Muslim people are obligated to avoid, as long as there are no medical alternatives (The British Board of Scholars \& Imams, 2020). Similarly, the Catholic Church announced that it is "morally acceptable" to receive the COVID-19 vaccine, which was endorsed by Pope Francis, even though the vaccine development process included using cell lines from aborted fetuses (Ladaria Ferrer, 2020). These statements coming from religious authorities are the examples of promoting COVID-19 vaccination while neutralizing false conspiracy theories against the vaccination. Therefore, if the vaccine hesitancy is related to certain religious beliefs, working with religious scholars and leaders would be an effective strategy as they could serve as trusted messengers to their religious groups. 


\section{Religion and Previous Health Crises}

Historically, religion has played a significant role in both threatening and improving public health during public health crises such as Ebola virus epidemic and the global HIV/AIDS epidemic (Blevins et al., 2019; Pargament et al., 2004; Pugh, 2010; VanderWeele, 2017). Before COVID-19, the Ebola virus disease was one of the most recent deadly epidemics that affected the West African region mainly in Guinea, Liberia, and Sierra Leone from December 2013 to June 2016. It caused 11,325 deaths with $40 \%$ of case fatality rate (Bell et al., 2016). Specifically, at the beginning of the epidemic, religious gatherings and practices that involved washing the body during burial practices accelerated the transmission of the Ebola virus, which is known to transmit through blood and bodily fluids. Furthermore, religious leaders refusing to adhere to public health guidelines imparted their understanding of the Ebola virus to their believers (Reichler et al., 2018). In response to this situation, the World Health Organization and several religious organizations such as the Catholic Agency for Overseas Development, Catholic Relief Services, and international faith-based organizations developed and disseminated a new protocol in November 2014 with the help of religious leaders, specifically with Muslim and Christian burial rituals and successfully controlled the epidemic by reducing cases in half (6,383 new cases in October 2014 whereas 3883 in November and 3060 in December) (Bell et al., 2016).

A similar impact of religion can be found with the HIV/AIDS epidemic. On the detrimental side, some religious groups have considered AIDS as a punishment for sins of homosexuality and/or adultery which, in turn, also made people with HIV/AIDS face great social stigma. On the beneficial side, religion has positively influenced psychological well-being including anxiety, depression, and quality of life among individuals who suffer from HIV/AIDS (Dalmida, Koenig, Holstad, \& Thomas, 2015; Pargament et al., 2004; VanderWeele, 2017). Furthermore, religion has been a key provider for HIV prevention, education, care, and support services over the past three decades (Blevins et al., 2019; VanderWeele, 2017). For instance, in Sub-Saharan Africa, one of the largest HIV support providers are faith-based organizations (U.S. President's Emergency Plan for AIDS Relief, 2015). In addition, in the late 1980s, various religious groups such as the Episcopal Church and Catholic Church started to cooperate with public health authorities to provide HIV/AIDS care and raise awareness (VanderWeele, 2017). All in all, the examples of previous epidemics have indicated diverse influences of religion as a double-edged sword when it comes to public health crises.

\section{Religion as a Social Determinant of Health and Intersectionality}

Religion as a social determinant of health has been largely overlooked and understudied (Kawachi, 2020; Ransome, 2020). According to the Public Health Agency of Canada (PHAC), social determinants of health include income and social status; social support networks; education; employment/working conditions; social environments; physical environments; personal health practices and coping skills; healthy child development; gender; and culture (Public Health Agency of Canada, 2016). 
Although religion is not mentioned as a social determinant of health in the PHAC report (2016), religion is encompassed in PHAC's conceptualization of social support networks presumably (Public Health Agency of Canada, 2016).

Our review demonstrated that religion plays a significant role in spreading as well as containing COVID-19, while potentially improving the health of religious population groups. This evidently indicates that religion is a definite social determinant of health and, thus, it is important to take religion into account when addressing public health issues. When social determinants of health including religion are addressed during public health crises such as COVID-19 pandemic, there are certain population groups that may need further attention, such as women, people of color, low-income families/individuals, or individuals at the intersection of these social identity variables (e.g., low-income, women of color). This is because when social determinants of health are interwoven with each other and jointly influence health, consequences can be more detrimental to their health.

The findings of our review indicated that culturally marginalized religious individuals experience religious stereotypes and stigma during COVID-19 which, in turn, influence their psychological health, thereby adding another layer of trauma to already overburdened individuals (Hashmi et al., 2020; Iqbal et al., 2020; Weinberger-Litman et al., 2020). For instance, such may be the case for some Muslim communities in North America, whose existence is at the nexus of racial and religious minorities. As evidently shown in our review, out of 10 studies that have provided epidemiological data on the outbreak and transmission of COVID-19, seven studies pertained to minoritized religious communities. Similar patterns were observed in the media where COVID-19 related outbreaks and transmission were more frequently reported in the minoritized faith communities globally (Jelowicki, 2020; Rahim, 2020; Wilson, 2020). Therefore, religion as a social determinant of health should be unquestionably but carefully addressed in the context of public health during COVID-19 pandemic.

\section{Overall Summary}

Religious groups have both accelerated and mitigated the spread of COVID-19 during the early stage of COVID-19 era. However, there are lessons to be learned from religious communities' endeavors to help people respond to and cope with COVID19 and prevent further religious-related outbreaks and spread. Most importantly, as the pandemic has not yet been eradicated, reconciliation between the practice of religious gatherings and public health guidelines, and a collaborative and pragmatic approach among religious communities, science, and government are critical to combat the COVID-19 crisis (Hashmi et al., 2020; Hong \& Handal, 2020).

This review summarized the literature addressing the varying roles of religion at the early stage of COVID-19 pandemic. Given that it only captures the roles of religion during the early stage of COVID-19 as the last search of literature was done in July 2020. A follow-up systematic review is warranted to further examine the roles of religion during the later stage of COVID-19. Furthermore, risk of bias for each article included in this review was not assessed given the emergency of the pandemic and to include all relevant literature available at the time of literature searches. 


\section{Conclusion}

This review summarized the literature addressing the varying roles of religion at the early stage of the COVID-19 pandemic. However, it only captures the roles of religion during the early stage of COVID-19, as the last search of this literature was completed in July 2020 and it did not include, for example, the work of 'chaplains' (e.g., 'hospital chaplain' or similar titles) who were undertaking duties on behalf of their religious organizations. A follow-up systematic review is warranted to further examine the roles of religion during the later stage of COVID-19. Furthermore, risk of bias for each article included in this review was not assessed given the emergency of the pandemic and to include all relevant literature immediately available at the time of literature searches. Understanding religion as a determinant of the transmission, mitigation, and/or adaptation of COVID-19 in the early stage is essential for collectively achieving success to end the pandemic. This review has provided information on religion and COVID-19 that can be used to develop pragmatic models and policies for future crises. As the pandemic has not yet been eradicated, there is an urgent need for further rigorous research on the role of religious communities during this time of COVID-19.

Studies on adaptation strategies that could be in place immediately are warranted to provide adequate and timely support for people when the COVID-19 pandemic is resolved as well as in preparation for future pandemics. Furthermore, as this review is focused on the roles of religious communities during the early stage of COVID19 , further research on how the roles have changed over time and how this alteration affected the transmission, mitigation, and/or adaptation of COVID-19 is needed.

\section{Appendix 1: Key Terms and Search Strings Used in Database Searches}

\begin{tabular}{ll}
\hline Database & Query \\
\hline CINAHL & ((MM "Coronavirus") OR (MM "COVID-19") OR " \\
& (((()(coronavirus or corona-virus) AND (wuhan or beijing or shanghai or Italy or \\
& South-Korea or korea or China or Chinese or 2019-nCoV or nCoV or COVID-19 \\
or Covid19 or SARS-CoV* or SARSCov2 or ncov)) OR (pneumonia AND Wuhan) \\
or "COVID-19" or "2019-nCoV" or "SARS-CoV" or SARSCOV2 or 2019-nCov or \\
"2019 coronavirus" or "2019 corona virus" or covid19 or ncov OR "novel corona \\
virus" or \\
"new corona virus" or "nouveau corona virus" or "2019 corona virus" OR "novel \\
coronavirus" or "new coronavirus" or "nouveau coronavirus" or "2019 coronavirus")) \\
AND (relig* OR spriritual* OR \\
cult OR "mass gathering*" OR christian* OR "religious practice*" OR \\
"religious event*" OR ritual OR belief* OR supernatural OR myth OR \\
"social determinant")" \\
Limiters-Published Date: 20,200,601-; English Language; Peer Reviewed; Research \\
Article; Human; Language: English \\
Expanders-Apply related words; Apply equivalent subjects \\
Search modes—-Boolean/Phrase
\end{tabular}




\begin{tabular}{|c|c|}
\hline Database & Query \\
\hline PubMed & 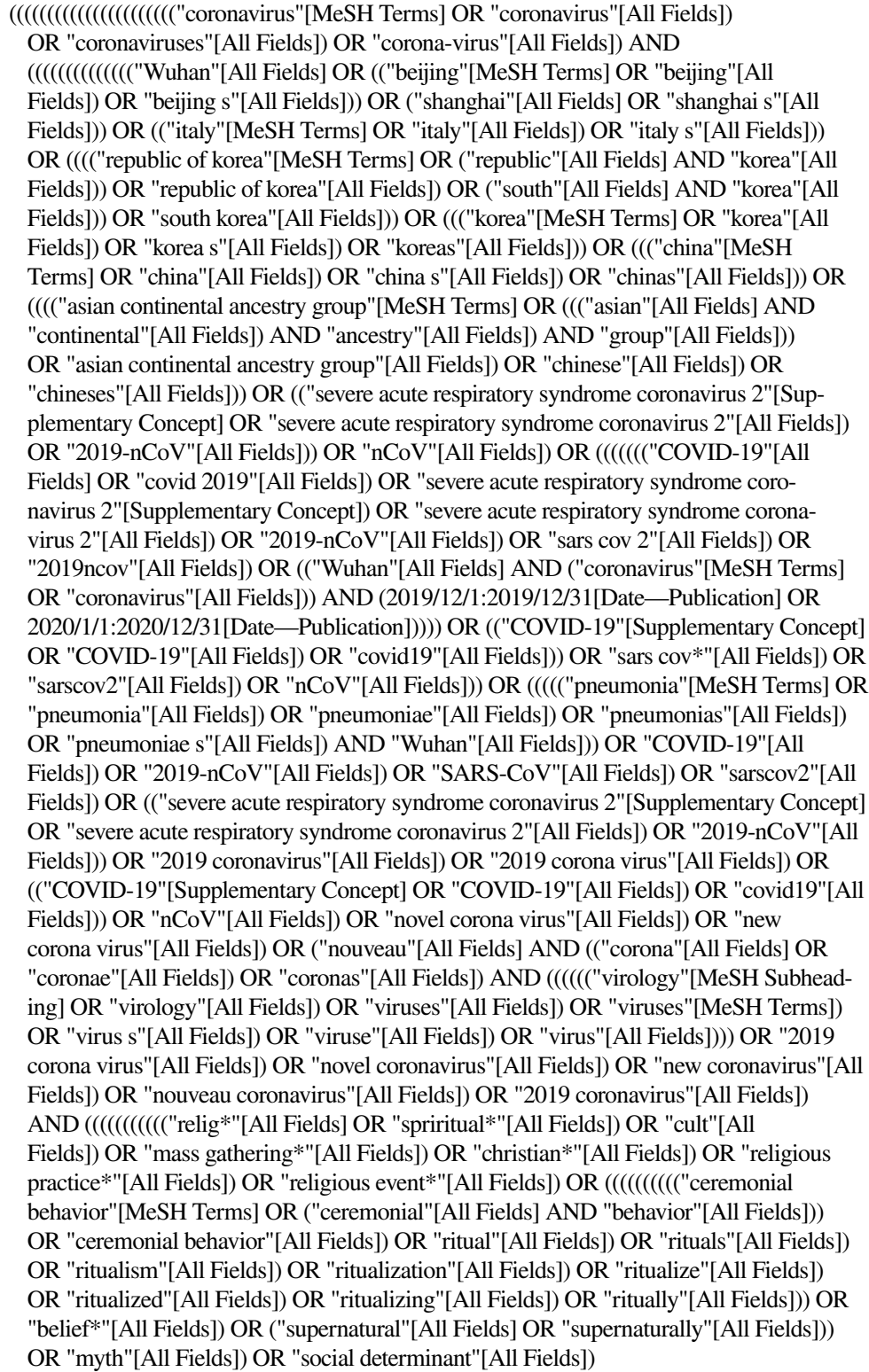 \\
\hline
\end{tabular}




\begin{tabular}{|c|c|}
\hline Database & Query \\
\hline PsycInfo & $\begin{array}{l}\text { 1. (coronavirus or covid or sars-cov* or sarscov2).mp. [mp = title, abstract, heading } \\
\text { word, table of contents, key concepts, original title, tests \& measures, mesh] (215) } \\
\text { 2. limit } 1 \text { to (human and english language and } \mathrm{yr}=" 2019 \text {-Current") }(59) \\
\text { 3. (relig* or spriritual* or cult or "mass gathering*" or christian* or "religious prac- } \\
\text { tice*" or "religious event*" or ritual or belief* or supernatural or myth or "social } \\
\text { determinant").mp. [mp = title, abstract, heading word, table of contents, key concepts, } \\
\text { original title, tests \& measures, mesh] }(227,354) \\
\text { 4. limit } 3 \text { to (human and english language and } \mathrm{yr}=\text { "2019 -Current") (6798) } \\
\text { 5. } 2 \text { and } 4 \text { (5) }\end{array}$ \\
\hline Web of Science & $\begin{array}{l}\text { TOPIC: })((((()(((()((()(((\text { coronavirus OR corona-virus) AND })(((()((()(((\text { wuhan OR } \\
\text { beijing) OR shanghai) OR Italy) OR South-Korea) OR korea) OR China) OR Chi- } \\
\text { nese) OR 2019-nCoV) OR nCoV) OR COVID-19) OR Covid19) OR SARS-CoV*) } \\
\text { OR SARSCov2) OR ncov)) OR (pneumonia AND Wuhan)) OR "COVID-19") OR } \\
\text { "2019-nCoV") OR "SARS-CoV") OR SARSCOV2) OR 2019-nCov) OR "2019 coro- } \\
\text { navirus") OR "2019 corona virus") OR coviden) OR ncov) OR "novel corona virus") } \\
\text { OR "new corona virus") OR "nouveau corona virus") OR "2019 corona virus") OR } \\
\text { "novel coronavirus") OR "new coronavirus") OR "nouveau coronavirus") OR "2019 } \\
\text { coronavirus") AND (((((((((((relig* OR spriritual*) OR cult) OR "mass gathering*") } \\
\text { OR christian*) OR ramadan) OR "religious practice*") OR "religious event*") OR } \\
\text { ritual) OR belief*) OR supernatural) OR myth) OR faith "social determinant")) } \\
\text { Timespan: All years. Indexes: SCI-EXPANDED, SSCI, A\&HCI, CPCI-S, CPCI-SSH, } \\
\text { ESCI }\end{array}$ \\
\hline imilar search & ings were used in LitCOVID, bioRXiv, and ATLA Religion databases \\
\hline
\end{tabular}

\section{Appendix 2: Descriptive Characteristics and Epidemiological Data of the Included Articles ( $N=58$ )}

\begin{tabular}{lllll}
\hline $\begin{array}{l}\text { Author and publica- } \\
\text { tion year }\end{array}$ & Study type & $\begin{array}{l}\text { Country (geographi- } \\
\text { cal location) }\end{array}$ & $\begin{array}{l}\text { Religious groups of } \\
\text { interest }\end{array}$ & $\begin{array}{l}\text { Epidemiological } \\
\text { statistics reported (yes/ } \\
\text { no; if yes: incidence, } \\
\text { outbreak, number } \\
\text { infected, R0, etc.) }\end{array}$ \\
\hline $\begin{array}{l}\text { Agley (2020) } \\
\begin{array}{l}\text { Ahmed and Memish } \\
(2020)\end{array}\end{array}$ & $\begin{array}{c}\text { Cross-sectional study } \\
\text { tion }\end{array}$ & US & N/A & N/A \\
\hline
\end{tabular}


Author and publica- $\quad$ Study type tion year
Country (geographi- Religious groups of cal location) interest
Epidemiological statistics reported (yes/ no; if yes: incidence, outbreak, number infected, R0, etc.)

"Six Jewish pilgrims were positively tested and confirmed by the beginning of March; therefore, 1,400 Italian and 200 Israeli visitors were quarantined. By March 15, 193 cases were confirmed in "Israel." It was reported that most of these cases may have been infected during the Jewish pilgrimages and other religious rituals." (p. 5815)

"Approximately 68.5\% of the confirmed CoVID-19 cases in the Middle East had visited Qom, whereas the rest of the confirmed cases visited other Shi'ite holy places, participated in Jewish pilgrimages, travelled as tourists, or flew in from Wuhan." (p. 5817)

N/A

Alzoubi et al. (2020)

Atique and Itumalla (2020)

\section{Letter to the Editor International}

Jordan

N/A

N/A

- Islam

"The first case of COVID-19 detected in a Saudi national who traveled from Iran to the Kingdom via Bahrain. Since then, COVID-19 cases have been increasing continuously and reached to 2795 cases as of 7 April 2020 [2]" (p. 2)

$\begin{array}{ll}\text { Capponi (2020) } & \begin{array}{c}\text { Special Section } \\ \text { article }\end{array}\end{array}$

- Neo-Pentecostal N/A

Churches

- Afro-Brazilian

Candomblé

- Umbanda 
Author and publica- Study type tion year
Country (geographi- Religious groups of

cal location) interest
Epidemiological statistics reported (yes/ no; if yes: incidence, outbreak, number infected, R0, etc.)

\begin{tabular}{|c|c|c|c|c|}
\hline $\begin{array}{l}\text { Chirico and Nucera } \\
\text { (2020) }\end{array}$ & Letter to the Editor & Italy & - Catholicism & $\begin{array}{l}\text { "An emergency national } \\
\text { law banned civil and } \\
\text { religious ceremonies, } \\
\text { including funerals, } \\
\text { to prevent the spread } \\
\text { of the virus (Larnaud } \\
\text { 2020). However, } \\
\text { officials have allowed } \\
\text { priests to say a prayer } \\
\text { at burials attended } \\
\text { by just a few of the } \\
\text { bereaved (Larnaud } \\
\text { 2020). Unfortunately, } \\
\text { an estimated 60 } \\
\text { priests in Italy have } \\
\text { died to date for the } \\
\text { Coronavirus pan- } \\
\text { demic (Mares 2020), } \\
\text { and } 16 \text { of them were } \\
\text { just resident in the } \\
\text { hard-hit Bergamo } \\
\text { Diocese, which } \\
\text { reported many more } \\
\text { hospitalized priests } \\
\text { (Cairns 2020)." (p. 2) }\end{array}$ \\
\hline
\end{tabular}


Author and publica- $\quad$ Study type tion year
Country (geographical location)
Religious groups of interest
Epidemiological statistics reported (yes/ no; if yes: incidence, outbreak, number infected, R0, etc.)

\begin{tabular}{|c|c|c|c|c|}
\hline Choi et al. (2020) & Case study & South Korea & $\begin{array}{l}\text { - Shincheonji Church } \\
\text { of Jesus } \\
\text { (New Religious } \\
\text { Movement) } \\
\text { - Christianity }\end{array}$ & $\begin{array}{l}\text { "On } 18 \text { February 2020, } \\
\text { a "super-spreader" } \\
\text { [5], attended a } \\
\text { gathering of a } \\
\text { religious sect called } \\
\text { the Shincheonji. This } \\
\text { 61-year-old woman, } \\
\text { known as "Patient } \\
\text { 31," was found to } \\
\text { have transmitted } \\
\text { SARS-CoV-2 to } \\
\text { an unusually large } \\
\text { number of people } \\
\text { who attended reli- } \\
\text { gious events in the } \\
\text { Shincheonji temple in } \\
\text { the southeastern city } \\
\text { of Daegu, home to } \\
\text { 2.5 million people } \\
\text { Approximately three- } \\
\text { quarters of the total } \\
\text { number of SARS- } \\
\text { CoV-2 cases ended } \\
\text { up being clustered } \\
\text { in Daegu, and, as of } \\
\text { March 2020, about } \\
60 \% \text { of the total } \\
\text { infections nationwide } \\
\text { were traced to this } \\
\text { religious group. } \\
\text { Daily infections rose } \\
\text { exponentially, near- } \\
\text { ing } 1000 . " \text { (p. } 3 \text { ) } \\
\text { "In March } 2020, \\
\text { other clusters were } \\
\text { reported outside of } \\
\text { worst-hit Daegu. At } \\
\text { River of Grace Com- } \\
\text { munity Church in } \\
\text { Gyeonggi Province, } \\
\text { more than } 80 \text { people } \\
\text { testive." }\end{array}$ \\
\hline $\begin{array}{l}\text { Chukwuorji and Iorfa } \\
\text { (2020) }\end{array}$ & Commentary & Nigeria & $\begin{array}{l}\text { - Christianity } \\
\text { - Islam }\end{array}$ & N/A \\
\hline $\begin{array}{l}\text { Crubézy and Telmon } \\
\text { (2020) }\end{array}$ & Letter & France & $\begin{array}{l}\text { - Judaism } \\
\text { - Islam }\end{array}$ & N/A \\
\hline $\begin{array}{l}\text { Ebrahim and Memish } \\
\text { (2020a) }\end{array}$ & $\begin{array}{l}\text { Rapid communica- } \\
\text { tion }\end{array}$ & Saudi Arabia & - Islam & N/A \\
\hline $\begin{array}{l}\text { Ebrahim and Memish } \\
\text { (2020b) }\end{array}$ & Commentary & International & $\begin{array}{l}\text { - Islam } \\
\text { - Catholicism }\end{array}$ & N/A \\
\hline
\end{tabular}


Author and publica- $\quad$ Study type tion year

\section{Country (geographi-} cal location)
Religious groups of interest
Epidemiological statistics reported (yes/ no; if yes: incidence, outbreak, number infected, R0, etc.)

\begin{tabular}{|c|c|c|c|c|}
\hline Escher (2020) & Editorial & International & $\begin{array}{l}\text { - Islam } \\
\text { - Catholicism } \\
\text { - Hinduism }\end{array}$ & N/A \\
\hline Freeman et al. (2020) & Cross-sectional study & UK & N/A & N/A \\
\hline Frei-Landau (2020) & Commentary & Israel & - Judaism & N/A \\
\hline $\begin{array}{l}\text { Galiatsatos et al. } \\
\text { (2020) }\end{array}$ & Community trial & US & N/A & N/A \\
\hline Gautret et al. (2020) & Letter to the Editor & International & - Islam & N/A \\
\hline Greene et al. (2020) & Commentary & $\begin{array}{l}\text { Not specified (written } \\
\text { in UK) }\end{array}$ & N/A & N/A \\
\hline На (2020) & $\begin{array}{l}\text { Short Communica- } \\
\text { tion }\end{array}$ & South Korea & $\begin{array}{l}\text { - Shincheonji Church } \\
\text { of Jesus } \\
\text { (New Religious } \\
\text { Movement) }\end{array}$ & N/A \\
\hline Hashmi et al. (2020) & $\begin{array}{l}\text { Impressionistic } \\
\text { Reporting }\end{array}$ & International & $\begin{array}{l}\text { - Islam } \\
\text { - Maronite }\end{array}$ & N/A \\
\hline Hill et al. (2020) & Cross-sectional study & US & - Christianity & N/A \\
\hline $\begin{array}{l}\text { Hong and Handal } \\
\text { (2020) }\end{array}$ & $\begin{array}{l}\text { Psychological Explo- } \\
\text { ration }\end{array}$ & US & $\begin{array}{l}\text { - Christianity } \\
\text { - Judaism }\end{array}$ & N/A \\
\hline Iqbal et al. (2020) & Letter & International & $\begin{array}{l}\text { - Islam } \\
\text { - Maronite }\end{array}$ & N/A \\
\hline JaJa et al. (2020) & Letter & South Africa & - Christianity & $\begin{array}{l}\text { "In the Free state prov- } \\
\text { ince, three church } \\
\text { leaders have since } \\
\text { tested positive after } \\
\text { leading the church } \\
\text { prayer service. Other } \\
\text { church leaders and } \\
\text { lay preachers who } \\
\text { attend the prayer } \\
\text { meeting have also } \\
\text { tested positive. To } \\
\text { date, over } 80 \% \text { of the } \\
\text { Free State COVID } \\
\text { emanated from this } \\
\text { single religious } \\
\text { event leading to the } \\
\text { infection of over } 80 \\
\text { persons and the fur- } \\
\text { ther tracing of } 1600 \\
\text { people who may have } \\
\text { been exposed to the } \\
\text { virus. [15]" (p. } 1078 \text { ) }\end{array}$ \\
\hline
\end{tabular}


Author and publica- $\quad$ Study type tion year
Country (geographical location)
Religious groups of interest
Epidemiological statistics reported (yes/ no; if yes: incidence, outbreak, number infected, R0, etc.)

\begin{tabular}{|c|c|c|c|c|}
\hline Kang (2020) & Perspective & South Korea & $\begin{array}{l}\text { - Shincheonji Church } \\
\text { of Jesus (New Reli- } \\
\text { gious Movement) }\end{array}$ & $\begin{array}{l}\text { "On March } 9,2020, \text { the } \\
\text { cumulative number } \\
\text { of confirmed cases } \\
\text { reached } 7382, \text { with } \\
51 \text { deaths in South } \\
\text { Korea. The Korean } \\
\text { government, based on } \\
\text { the church member } \\
\text { registry of } 244743 \\
\text { believers it acquired } \\
\text { from the Shincheonji } \\
\text { authorities, analyzed } \\
\text { connections among } \\
\text { the church members } \\
\text { and found } 4212 \\
\text { confirmed COVID- } \\
19 \text { cases by March } 2, \\
2020 . \text { According to } \\
\text { the analysis, } 93 \% \text { of } \\
\text { the confirmed cases } \\
\text { were related to the } \\
\text { Shincheonji Church. } \\
\text { [5]". (p. 169) }\end{array}$ \\
\hline Kim et al. (2020) & Brief Report & South Korea & $\begin{array}{l}\text { - Shincheonji Church } \\
\text { of Jesus (New Reli- } \\
\text { gious Movement) }\end{array}$ & $\begin{array}{l}\text { As of March } 3,2020, \\
2992 \text { of } 5621 \text { cases } \\
\text { were related to the } \\
\text { Shincheonji religious } \\
\text { group } \\
\text { The authors "obtained } \\
\text { data of laboratory- } \\
\text { confirmed cases } \\
\text { related to the } \\
\text { Shincheonji religious } \\
\text { group from press } \\
\text { releases by Korean } \\
\text { public health } \\
\text { authorities and news } \\
\text { reports. [...] and } \\
\text { analyzed data from } \\
59 \text { cases (median age, } \\
30 \text { years)." (p. } 164 \text { ) } \\
\text { "The average period } \\
\text { between the date of } \\
\text { illness onset and the } \\
\text { date of COVID-19 } \\
\text { confirmation was } \\
5.2 \text { days, with a } \\
\text { median of } 4 \text { days } \\
\text { (range, 0-13)." (p. } \\
165 \text { ) }\end{array}$ \\
\hline
\end{tabular}


Author and publica- $\quad$ Study type tion year
Country (geographi-

cal location)
Religious groups of

interest
Epidemiological statistics reported (yes/ no; if yes: incidence, outbreak, number infected, R0, etc.)

\begin{tabular}{|c|c|c|c|c|}
\hline Koenig (2020a) & Commentary & International & $\begin{array}{l}\text { - Christianity } \\
\text { - Judaism } \\
\text { - Islam } \\
\text { - Buddhism } \\
\text { - Hinduism }\end{array}$ & N/A \\
\hline Koenig (2020b) & Original Paper & International & $\begin{array}{l}\text { - Christianity } \\
\text { - Islam } \\
\text { - Judaism } \\
\text { - Buddhism } \\
\text { - Hinduism }\end{array}$ & N/A \\
\hline Lan et al. (2020) & Observational study & $\begin{array}{l}\text { Hong Kong } \\
\text { Japan } \\
\text { Singapore } \\
\text { Taiwan } \\
\text { Thailand } \\
\text { Vietnam }\end{array}$ & N/A & $\begin{array}{l}\text { Religious professionals } \\
\text { were one of the most } \\
\text { common occupations } \\
\text { during both early ( } 3 \\
\text { out of } 31) \text { and late ( } 3 \\
\text { out of } 72 \text { ) transmis- } \\
\text { sion ( } \mathrm{n}=6 \text { out of } \\
\text { 103) }(p=0.362)\end{array}$ \\
\hline Lee $(2020)$ & Cross-sectional study & US & N/A & No \\
\hline Lee $(2020)$ & Cross-sectional study & US & N/A & No \\
\hline Levin (2020) & Original Paper & US & $\begin{array}{l}\text { - Evangelicalism } \\
\text { and conservative } \\
\text { Christianity } \\
\text { - Judaism } \\
\text { - Shia Islam } \\
\text { - Buddhism } \\
\text { - Catholicism }\end{array}$ & No \\
\hline Lorea (2020) & $\begin{array}{l}\text { Special Section } \\
\text { Article }\end{array}$ & $\begin{array}{l}\text { International (article } \\
\text { written in Singa- } \\
\text { pore) }\end{array}$ & $\begin{array}{l}\text { - Islam } \\
\text { - Catholicism } \\
\text { - Hinduism } \\
\text { - Greek Orthodox }\end{array}$ & No \\
\hline
\end{tabular}


Author and publica- $\quad$ Study type tion year
Country (geographi- Religious groups of interest cal location)

Epidemiological statistics reported (yes/ no; if yes: incidence, outbreak, number infected, R0, etc.)

\begin{tabular}{|c|c|c|c|c|}
\hline Mat et al. (2020) & $\begin{array}{l}\text { Rapid communica- } \\
\text { tion }\end{array}$ & $\begin{array}{l}\text { Malaysia with further } \\
\text { international } \\
\text { spread }\end{array}$ & - Islam & $\begin{array}{l}\text { As of April 13, } 2020, \\
\text { Malaysia had } 4817 \\
\text { confirmed cases and } \\
77 \text { deaths due to } \\
\text { COVID-19 } \\
\text { "More than } 35 \% \text { of the } \\
\text { COVID-19 cases } \\
\text { in Malaysia were } \\
\text { directly linked to the } \\
\text { Sri Petaling mass } \\
\text { gatherings that took } \\
\text { place between Febru- } \\
\text { ary } 27,2020 \text { and } \\
\text { March } 1,2020 . \text { The } \\
\text { Sri Petaling gathering } \\
\text { is a Moslem mis- } \\
\text { sionary movement } \\
\text { attended by more } \\
\text { than } 19000 \text { people, } \\
\text { including } 1500 \text { from } \\
\text { India, South Korea, } \\
\text { Brunei, China, Japan, } \\
\text { Vietnam, Philippines, } \\
\text { Myanmar, Cambodia, } \\
\text { Singapore, and } \\
\text { Thailand." (p. 1) }\end{array}$ \\
\hline $\begin{array}{l}\text { McCloskey et al. } \\
\text { (2020a) }\end{array}$ & Commentary & $\begin{array}{l}\text { International (exem- } \\
\text { plified Umrah in } \\
\text { Saudi Arabia) }\end{array}$ & - Islam & No \\
\hline $\begin{array}{l}\text { McCloskey et al. } \\
\text { (2020b) }\end{array}$ & Correspondence & $\begin{array}{l}\text { International (exem- } \\
\text { plified Hajj in } \\
\text { Saudi Arabia) }\end{array}$ & - Islam & No \\
\hline McLaughlin (2020) & Preliminary Report & Japan & $\begin{array}{l}\text { - Buddhism } \\
\text { - Shinto } \\
\text { - New religions }\end{array}$ & No \\
\hline Memish et al. (2020) & Correspondence & International & - Islam & No \\
\hline $\begin{array}{l}\text { Modell and Kardia } \\
\text { (2020) }\end{array}$ & $\begin{array}{l}\text { Philosophical Explo- } \\
\text { ration }\end{array}$ & US (Detroit) & $\begin{array}{l}\text { - Greek Orthodox } \\
\text { - Judaism } \\
\text { - Christianity }\end{array}$ & No \\
\hline $\begin{array}{l}\text { Muurlink and Taylor- } \\
\text { Robinson (2020) }\end{array}$ & Opinion & International & $\begin{array}{l}\text { - Islam } \\
\text { - Traditionalist } \\
\text { Christian Church } \\
\text { - Ultra-Orthodox } \\
\text { Judaism }\end{array}$ & No \\
\hline Nahandi et al. (2020) & Commentary & Iran & - Islam & No \\
\hline Peteet (2020) & $\begin{array}{l}\text { Impressionistic } \\
\text { Reporting }\end{array}$ & International & - Judaism & No \\
\hline Prime et al. (2020) & Review & International & N/A & No \\
\hline
\end{tabular}


Author and publica- $\quad$ Study type tion year
Country (geographi-

cal location)
Religious groups of interest
Epidemiological statistics reported (yes/ no; if yes: incidence, outbreak, number infected, R0, etc.)

\begin{tabular}{|c|c|c|c|c|}
\hline Quadri (2020) & Perspective & International & $\begin{array}{l}\text { - Islam } \\
\text { - Shincheonji Church } \\
\text { (New Religious } \\
\text { Movement) } \\
\text { - Hinduism }\end{array}$ & No \\
\hline $\begin{array}{l}\text { Safdar and Yasmin } \\
\text { (2020) }\end{array}$ & $\begin{array}{l}\text { Qualitative (semi- } \\
\text { structured indi- } \\
\text { vidual interview) } \\
\text { study }\end{array}$ & Pakistan & - Islam & No \\
\hline Shah et al. (2020) & Commentary & US & N/A & No \\
\hline $\begin{array}{l}\text { Tarimo and Wu } \\
\text { (2020) }\end{array}$ & Letter to the editor & Tanzania & N/A & No \\
\hline $\begin{array}{l}\text { Thompkins et al. } \\
\text { (2020) }\end{array}$ & Commentary & US & - Christianity & No \\
\hline $\begin{array}{l}\text { Tootee and Larijani } \\
\text { (2020) }\end{array}$ & Editorial & International & - Islam & No \\
\hline $\begin{array}{l}\text { Umucu and Lee } \\
\text { (2020) }\end{array}$ & Cross-sectional study & US & N/A & No \\
\hline $\begin{array}{l}\text { Waitzberg } \\
\text { et al. (2020) }\end{array}$ & Commentary & Israel & $\begin{array}{l}\text { - Ultra-Orthodox } \\
\text { Judaism } \\
\text { - Islam }\end{array}$ & No \\
\hline $\begin{array}{l}\text { Waqar and Ghour } \\
\text { (2020) }\end{array}$ & Commentary & International & - Islam & No \\
\hline $\begin{array}{l}\text { Weinberger-Litman } \\
\text { et al. }(2020)\end{array}$ & Cross-sectional study & US & $\begin{array}{l}\text { - Modern Orthodox } \\
\text { Jewish }\end{array}$ & No \\
\hline $\begin{array}{l}\text { Wildman et al. } \\
\text { (2020) }\end{array}$ & Editorial & International & $\begin{array}{l}\text { - Shincheonji Church } \\
\text { (New Religious } \\
\text { Movement) } \\
\text { - Christianity }\end{array}$ & No \\
\hline Wong et al. (2020) & Letter to the editor & International & - Islam & No \\
\hline $\begin{array}{l}\text { Yezli and Khan } \\
\text { (2020a) }\end{array}$ & Perspective & International & $\begin{array}{l}\text { Various religious } \\
\text { events (not speci- } \\
\text { fied) provided with } \\
\text { countries }\end{array}$ & No \\
\hline
\end{tabular}




\begin{tabular}{|c|c|c|c|c|}
\hline $\begin{array}{l}\text { Author and publica- } \\
\text { tion year }\end{array}$ & Study type & $\begin{array}{l}\text { Country (geographi- } \\
\text { cal location) }\end{array}$ & $\begin{array}{l}\text { Religious groups of } \\
\text { interest }\end{array}$ & $\begin{array}{l}\text { Epidemiological } \\
\text { statistics reported (yes/ } \\
\text { no; if yes: incidence, } \\
\text { outbreak, number } \\
\text { infected, R0, etc.) }\end{array}$ \\
\hline $\begin{array}{l}\text { Yezli and Khan } \\
\text { (2020b) }\end{array}$ & Commentary & $\begin{array}{c}\text { The Kingdom of } \\
\text { Saudi Arabia }\end{array}$ & - Islam & $\begin{array}{l}\text { "On the 2nd of March } \\
\text { 2020, the first case } \\
\text { of COVID-19 was } \\
\text { reported by the Saudi } \\
\text { authorities. The case } \\
\text { was an exported case } \\
\text { in a Saudi national } \\
\text { returning from Iran } \\
\text { via Bahrain." [...] Up } \\
\text { to the 9th of March } \\
\text { 2020, only imported } \\
\text { cases were reported } \\
\text { in KSA (Kingdom of } \\
\text { Saudi Arabia). On the } \\
\text { 10th of March 2020, } \\
\text { with a total of } 20 \\
\text { COVID-19 cases and } \\
\text { five new confirmed } \\
\text { cases, local transmis- } \\
\text { sion was documented } \\
\text { in the country." (p. 2) }\end{array}$ \\
\hline
\end{tabular}

N/A: Not available

\section{Appendix 3: Summary of Findings of the Included Articles $(\mathbf{N}=\mathbf{5 8})$}

\begin{tabular}{llll}
\hline $\begin{array}{l}\text { Author and } \\
\text { publication year }\end{array}$ & Key interest & $\begin{array}{l}\text { Reported role of } \\
\text { religion in COVID- } \\
19\end{array}$ & Summary of the findings \\
\hline Agley (2020) & $\begin{array}{c}\text { Religious com- } \\
\text { mitment }\end{array}$ & Mistrust & $\begin{array}{l}\text { " "High religious commitment was associ- } \\
\text { ated with significantly less overall trust in } \\
\text { science" (p. 122) }\end{array}$ \\
$\begin{array}{l}\text { Ahmed and } \\
\text { Memish (2020) }\end{array}$ & $\begin{array}{l}\text { Banning of reli- } \\
\text { gious events } \\
\text { (Hajj 2020 } \\
\text { and Umrah) }\end{array}$ & Mitigation & $\begin{array}{l}\text { In July 2020, the Hajj was planned to } \\
\text { receive pilgrims to Mecca, Kingdom of } \\
\text { Saudi Arabia (KSA) from all over the } \\
\text { world. The authors recommend Hajj to be } \\
\text { cancelled; "KSA in canceling Hajj 2020 } \\
\text { well in advance of the events would be } \\
\text { very much in line with Islamic ideals and } \\
\text { would contribute greatly to the safety of } \\
\text { humanity" (p. 2) }\end{array}$ \\
& &
\end{tabular}




\begin{tabular}{llll}
\hline $\begin{array}{l}\text { Author and } \\
\text { publication year }\end{array}$ & Key interest & $\begin{array}{l}\text { Reported role of } \\
\text { religion in COVID- } \\
19\end{array}$ & Summary of the findings \\
& &
\end{tabular}

\begin{tabular}{lcc}
\hline Al-Rousan and & Sunnis and Shi & Spread, Mistrust/ \\
Al-Najjar & ites, Jewish & Misinformation \\
(2020) & pilgrimage to & and Mitigation \\
& Israel &
\end{tabular}

- "Several cases visited Qom for spiritual treatment and recovery from coronavirus infection. This is because Shi 'ites believe that visiting shrines and performing religious rites help in healing coronavirus infection and prevent further transmission ${ }^{23}$." (p. 5816)

- "Jewish pilgrims may have spread CoVID19 to Israel via religious rituals as well. Jewish pilgrims who visited Italy or came from Italy had infected several individuals in Palestine" (p. 5817)

- "Thus, we infer that visiting Qom and other Shi'ite sites, Jewish pilgrimages and open tourism are the three major factors that have facilitated the spread of CoVID19 in the Middle East, whereas visiting Qom and other shrines in Iran is the main transmission route for CoVID-19 in the Gulf countries." (p. 5817)

$\begin{array}{lll}\begin{array}{c}\text { Ali and Alharbi } \\ (2020)\end{array} & \begin{array}{c}\text { Banning of reli- } \\ \text { gious events } \\ \text { (Hajj 2020 }\end{array} & \\ & \text { Mitigation } \\ \text { and Umrah) } & \\ \begin{array}{c}\text { Alzoubi et al. } \\ (2020)\end{array} & \text { Religious belief } & \begin{array}{c}\text { Mistrust/misinfor- } \\ \text { mation }\end{array}\end{array}$

Atique and Itumalla (2020)
Banning of reli- Spread and Mitigagious events tion

(Hajj 2020 and Umrah)
- "The Kingdom of Saudi Arabia has provisionally banned Umrah (pilgrimage) for the pilgrims to Mecca and Medina (the two holiest cities of the Islam religion)" (p. 5)

- "Around $10 \%$ of students believed that their religious beliefs and body immunity might protect them from infection." [...] "The main sources of knowledge were social media, Internet, and television." (p. 17)

- "It is important to recognize that COVID19 has infected the people who had a travel history and it may lead to local as well as global transmissions in the countries from where the people are coming to perform the religious rituals and vice versa" (p. 2)

- "It is highly likely that the religious mass gatherings in terms of Umrah and Hajj may turn into potential superspreader of the pandemic [7] [...]". (p. 2) 


\begin{tabular}{lll}
\hline $\begin{array}{l}\text { Author and } \\
\text { publication year }\end{array}$ & Key interest & $\begin{array}{l}\text { Reported role of } \\
\text { religion in COVID- } \\
19\end{array}$ \\
\hline Capponi (2020) & $\begin{array}{l}\text { Religious and } \\
\text { scientific } \\
\text { conflicts, } \\
\text { Discrepancy } \\
\text { in leader- } \\
\text { ship among } \\
\text { religions }\end{array}$ & $\begin{array}{c}\text { Mistrust/Misinfor- } \\
\text { mation }\end{array}$ \\
& & \\
&
\end{tabular}

Summary of the findings

religions

Chirico and Nuc- Spiritual skills era (2020) for healthcare workers
Adaptation

- The author described different ways of elaborating beliefs and behaviors during COVID-19 between Neo-Pentecostal Churches (which endorsed the current president, Bolsonaro) and religious minorities like Afro-Brazilian Candomblé and Umbanda

- "Afro-religious authorities gave practical information about sanitary prevention and social distancing, and some announced the temporary suspension of all public ritual activities. In addition, they suggested hygienic measure like avoiding kissing each other's hands (a common form for greeting and asking one's blessing)." (p. 1)

- "Neo-Pentecostal churches proposed a very different narrative. [...] not to fear the virus, as God would protect those who have faith." (p. 1)

- "Neo-Pentecostal churches always displayed a privileged and sophisticated use of digital media (social networks, TV channels, live streaming sessions, etc.), they are now stressing the importance of in-presence attendance of services." [...] "Conversely, Afro-religious practitioners, who value bodily engagement and physical presence more than abstract spiritual commitment, have been long reluctant to occupy online spaces and to post content online, [...] The COVID-19 crisis allowed them to occupy online spaces they had avoided in the past." (p. 2)

- " [...] spirituality has been already recognized as an essential part in certain medical fields like the palliative care (Pink et al. 2007)" (p. 2)

- The authors argued that "spiritual skills for healthcare workers are even more important in a disaster scenario like this COVID 19 pandemic, to relieve stress and psychic sufferance of the same healthcare professionals as well as of patients and their families." (p. 2)

- "For this reason, spiritual skills should be recognized as "core" skills for healthcare professionals and be implemented in all medical curricula." (p. 2) 


\begin{tabular}{lll}
\hline $\begin{array}{l}\text { Author and } \\
\text { publication year }\end{array}$ & Key interest & $\begin{array}{l}\text { Reported role o } \\
\text { religion in CO } \\
19\end{array}$ \\
\hline Choi et al. (2020) & $\begin{array}{l}\text { Religious sect } \\
\text { and gather- } \\
\text { ings }\end{array}$ & $\begin{array}{l}\text { Outbreak and } \\
\text { Spread }\end{array}$ \\
\end{tabular}

Summary of the findings religion in COVID-

- "The Shincheonji super-spreader developed a fever on 10 February 2020 but attended four Shincheonji events before being diagnosed with SARS-CoV-2. Public health authorities determined that this huge transmission was due to the behavioral characteristics of the religious group: members sit side-by-side in a cramped space for a significant amount of time during their temple service. This reinforced awareness of the need for social distancing, and the importance of following SARS-CoV-2 guidelines to avoid such places." (p. 3)

- "Due to the reclusive and secretive nature of the religious sect, uncertainty in tracking escalated the outbreak. Group members, including "Patient 31," tried to refuse diagnostic testing, thereby spreading the virus. While public health authorities have not found the precise epidemiological link between Patient 31 and her source of infection, further investigation by the Center for Disease Control showed that group members traveled between South Korea and their Wuhan, China fringe branches in January 2020." (p. 3)

- "In March 2020, other clusters were reported outside of worst-hit Daegu. At River of Grace Community Church in Gyeonggi Province, more than 80 people tested positive. These cases drew international attention, as security camera footage showed church leaders spraying saltwater into followers' mouths, as they believed that this practice would protect them from SARS-CoV-2." (p. 3)

- "Even in South Korean society, where in modern history citizens often had to cede control over their private information to government authorities, this aggressive system of contact tracing sparked fears and dissent, particularly among minorities, such as religious sects, foreigners, and LGBT people. These text messages, indicating precise knowledge of one's whereabouts at a specific day and time, were understandably ill-received, as was the knowledge of credit card monitoring." (p. 9) 


\begin{tabular}{llll}
\hline $\begin{array}{l}\text { Author and } \\
\text { publication year }\end{array}$ & Key interest & $\begin{array}{l}\text { Reported role of } \\
\text { religion in COVID- } \\
19\end{array}$ & Summary of the findings \\
& &
\end{tabular}

Chukwuorji and
Iorfa (2020)

- "According to the chairman of the Nigerian Medical Association, many religious leaders in the predominantly Muslim northern part of Nigeria did not also believe in coronavirus spread (see https:// www.youtube.com/watch?vKB7jww54O Os)." (p. 189)

- "Nigeria is a country where church and mosque gatherings are a consistent part of everyday life, and some religious leaders preach that believers in these faiths are "immune" to the contagious disease (Lichtenstein, Ajayi, \& Egbunike, 2020)." (p.189)

- "Regarding personal measures, fearinduced behavioral changes such as heat therapy and consuming lemon, ginger, garlic, local herbs, and other substances for protection are becoming commonplace as reported by people in the social media." (p.189)

Crubézy and Telmon (2020)
Funerary rituals Mitigation

- The authors made recommendations for funerary rituals during the pandemic to limit contagion while allowing families to grieve and preserving the dignity of the deceased such as minimal body washing (body wetting without manual scrubbing)

- The authors added that "Jewish religion the "tahara", the rite of purification of the body of the deceased, must be prohibited; no embalming; for Muslim religion, the Tayammum (dry toilet by placing both hands on a stone or earth) may be sufficient." (p. 22) 


\begin{tabular}{llll}
\hline $\begin{array}{l}\text { Author and } \\
\text { publication year }\end{array}$ & Key interest & $\begin{array}{l}\text { Reported role of } \\
\text { religion in COVID- } \\
19\end{array}$ & Summary of the findings \\
& &
\end{tabular}

\begin{tabular}{cl}
\hline Ebrahim and & Banning of reli- \\
Memish & Mitigation \\
(2020a) & (Hajj 2020 \\
& and Umrah)
\end{tabular}

Ebrahim and

Memish

(2020b)
Banning of reli- Mitigation gious events

(Hajj 2020

and Umrah)
- "Hajj pilgrims are exposed to didactic health education sessions as part of their preparedness package, but Umrah pilgrims do not received any." (p. 1)

- "Because the Umrah crowd size in ritual sites are smaller than that during Hajj, more elderly and disabled persons would be seen during Umrah.” (p. 1)

- The authors recommended Umrah to be cancelled

- The authors highlighted that "KSA's decision to suspend Umrah pilgrimage services comes with a huge cost to the economy of KSA including the airline, transport and hospitality sector, and adversely affects the employment and livelihood of the native and immigrant workforce of holy cities of KSA. [...] "Above all, pilgrimage is lifetime dream of people of Muslim faith, and many save up money for their entire lives to achieve their eternal dream. Many even express preference to die at the holy sites and consider it as a blessing. Therefore, the emotional and mental challenges experienced by would-be pilgrims who are affected by the suspension are unquantifiable." (p. 1-2)

- "Mass gatherings, both those are clearly defined and spontaneously occurring, are key determinants of epidemiologic expansion of disease outbreaks." (p. 3)

- The authors argued "Cancellation of suspension of mass gatherings would be critical to pandemic mitigation" based on the past experiences with respiratory diseases (p. 2). Religion-related mass gatherings include Hajj, Arba een, Namugongo Martyrs Day and Qom Shia pilgrimage 


\begin{tabular}{|c|c|c|c|}
\hline $\begin{array}{l}\text { Author and } \\
\text { publication year }\end{array}$ & Key interest & $\begin{array}{l}\text { Reported role of } \\
\text { religion in COVID- } \\
19\end{array}$ & Summary of the findings \\
\hline Escher (2020) & $\begin{array}{l}\text { Banning of } \\
\text { religious } \\
\text { events (Hajj, } \\
\text { Lourdes and } \\
\text { Kumbh Mela) }\end{array}$ & Mitigation & $\begin{array}{l}\text { - "The WHO defines a mass gathering as a } \\
\text { "concentration of people at a specific loca- } \\
\text { tion for a specific purpose over a set period } \\
\text { of time which has the potential to strain } \\
\text { the planning and response resources of the } \\
\text { country or community."” (p. 2) } \\
\text { - "Religious pilgrimages such as the Hajj } \\
\text { in Islam and Lourdes in Catholicism } \\
\text { draw millions of pilgrims every year. The } \\
\text { triennial Kumbh Mela, the Hindu religious } \\
\text { pilgrimage festival, can draw up to } 120 \\
\text { million people over two months. The } \\
\text { health and safety of vulnerable populations } \\
\text { in such events are quiet challenging." (p. 2) } \\
\text { "Recent consequences of this standard } \\
\text { have resulted in the cancellation of mass } \\
\text { gatherings in Lourdes and the closure by } \\
\text { Saudi Arabia of pilgrims to Umrah." (p. 2) }\end{array}$ \\
\hline $\begin{array}{l}\text { Freeman et al. } \\
(2020)\end{array}$ & $\begin{array}{l}\text { Religiosity and } \\
\text { conspiracy } \\
\text { beliefs }\end{array}$ & $\begin{array}{l}\text { Mistrust/Misinfor- } \\
\text { mation }\end{array}$ & $\begin{array}{l}\text { - "Holding specific or general coronavirus } \\
\text { conspiracy beliefs was associated with } \\
\text { higher levels of religiosity [...]" (p. 12) } \\
\text { - "Conspiracy beliefs are likely to be both } \\
\text { indexes and drivers of societal corrosion. } \\
\text { They matter in this context because they } \\
\text { may well have reduced compliance with } \\
\text { government social distancing guidelines, } \\
\text { thereby contributing to the spread of the } \\
\text { disease." (p. 12) } \\
\text { "We believe it is more likely that con- } \\
\text { spiracy beliefs drive behaviour or at the } \\
\text { very least remove barriers to carrying out } \\
\text { unhelpful behaviours." (p. 13) }\end{array}$ \\
\hline
\end{tabular}




\begin{tabular}{llll}
\hline $\begin{array}{l}\text { Author and } \\
\text { publication year }\end{array}$ & Key interest & $\begin{array}{l}\text { Reported role of } \\
\text { religion in COVID- } \\
19\end{array}$ & Summary of the findings \\
& &
\end{tabular}

\begin{tabular}{ccc}
\hline Frei-Landau & Religious ways & Mitigation and \\
(2020) & of coping & Adaptation
\end{tabular}

$\begin{array}{cl}\text { Galiatsatos et al. } & \begin{array}{c}\text { Developing } \\ \text { medical- }\end{array} \\ & \begin{array}{l}\text { religious } \\ \text { partnerships }\end{array}\end{array}$

- "In Israel, a quarantine policy was first announced on March 9, 2020; then, using emergency legislation, it was gradually made more restrictive, forbidding the gathering of more than two people, with the exception of funerals and circumcision ceremonies. Consequently, all synagogues were forced to close, and all religious interactions in the public sphere had to cease, including prayer rituals. This change had the potential to threaten religious Jews' sense of belonging and well-being." (p. 258)

- "Jewish precepts require believers to pray three times a day within a minyan - a group of at least 10 men and women; consequently, Jewish individuals gather frequently in the synagogues, where they meet the same community members." (p. 258)

- "In Israel, Jewish religious leaders established three novel adaptations to customary rituals performed in both the public and private arenas: 1) A "balcony" minyan; 2) Online chavruta video conferencing; and 3) broadcasting the Passover ceremony." (p. 259)

- The authors suggested that the adaptations that Jewish religious leaders made to long-standing rulings to address the issues of belonging and resilience during the pandemic

- The authors initiated a community conference call series, twice a week, for $60 \mathrm{~min}$. "The breakdown of the call's timeline generally included a 5-min introduction, $15 \mathrm{~min}$ of COVID-19 updates, 15-20 min on a specific COVID-19 health issues, $10 \mathrm{~min}$ of questions from callers, and a closing mediation for the final $5 \mathrm{~min}$. On Friday calls, we invited community leaders to share their thoughts on their community needs and successes (5-10 $\mathrm{min}) . "$ [...] "Meditations were meant to be inclusive of all faith traditions and non-sectarian in their focus." (p. 2258)

- "The community calls have identified the need for a significant role moving forward: assisting religious leaders in understanding how to assure the public safety of congregants as quarantine measures begin to be scaled back." (p. 2261) 


\begin{tabular}{llll}
\hline $\begin{array}{l}\text { Author and } \\
\text { publication year }\end{array}$ & Key interest & $\begin{array}{l}\text { Reported role of } \\
\text { religion in COVID- } \\
19\end{array}$ & Summary of the findings \\
& &
\end{tabular}

\begin{tabular}{|c|c|c|c|}
\hline $\begin{array}{l}\text { Gautret et al. } \\
\text { (2020) }\end{array}$ & $\begin{array}{l}\text { Banning of reli- } \\
\text { gious events } \\
\text { (Hajj } 2020 \\
\text { and Umrah) }\end{array}$ & Mitigation & $\begin{array}{l}\text { - "If travel restrictions are successful in } \\
\text { avoiding the extension of the outbreak } \\
\text { to the Kingdom of Saudi Arabia in the } \\
\text { following months, authorities may have to } \\
\text { restrict temporarily the entry of pilgrims } \\
\text { from affected countries into KSA as was } \\
\text { done during the Evola outbreak } 2016 \text { [6]." } \\
\text { (p. 1) }\end{array}$ \\
\hline $\begin{array}{l}\text { Greene et al } \\
(2020)\end{array}$ & $\begin{array}{l}\text { Religious } \\
\text { leaders of } \\
\text { faith-based } \\
\text { communities }\end{array}$ & Adaptation & $\begin{array}{l}\text { - "One area that has not yet been addressed } \\
\text { in the academic literature, but may be } \\
\text { particularly relevant in the COVID-19 pan- } \\
\text { demic, is that of moral injury in religious } \\
\text { leaders. Moral injury has been defined } \\
\text { as the psychological distress caused by } \\
\text { actions, or their omission, that violate an } \\
\text { individual's moral cold (Litz et al., 2009)." } \\
\text { (p. 1) } \\
\text { - The authors suggested recommendations } \\
\text { regarding psychological stressors for reli- } \\
\text { gious leaders and ways to cope with moral } \\
\text { injury, burnout, and secondary trauma due } \\
\text { to the COVID-19 pandemic: "(1) self-care; } \\
\text { (2) spirituality; (3) acknowledge moral } \\
\text { conflicts; (3) purpose; (4) supervision and } \\
\text { peer support; (5) social support; and (6) } \\
\text { professional support." (p. 2) }\end{array}$ \\
\hline На (2020) & $\begin{array}{l}\text { Religious gath- } \\
\text { erings }\end{array}$ & Mitigation & $\begin{array}{l}\text { - "A fringe religious cult, the Shincheonji } \\
\text { Church of Jesus (or the Temple of the } \\
\text { Tabernacle of the Testimony), has turned } \\
\text { into a super spreader by allowing close } \\
\text { proximity among believers in its study } \\
\text { room or during prayer sessions." (p. 1) } \\
\text { - The author argued that "religious organiza- } \\
\text { tions should maintain bipartisanship with } \\
\text { science by prohibiting close proximity } \\
\text { among believers." (p. 2) }\end{array}$ \\
\hline
\end{tabular}




\begin{tabular}{llll}
\hline $\begin{array}{l}\text { Author and } \\
\text { publication year }\end{array}$ & Key interest & $\begin{array}{l}\text { Reported role of } \\
\text { religion in COVID- } \\
19\end{array}$ & Summary of the findings \\
\hline
\end{tabular}

\begin{tabular}{cl}
\hline Hashmi et al. & Religious \\
(2020) & Cliché \\
& and Stigma, \\
& Institutional \\
& collabora- \\
& tion between \\
& religion and \\
& healthcare \\
& professionals
\end{tabular}

Hill et al. (2020) State religiosity Mistrust/Misinforand population mobility
- "For decades, religion has provided explanations and answers to existential questions and queries that can emerge during a pandemic. This characteristic of religion has helped communities in finding answers and meanings to their confusions." (p. 1)

- The authors argued that "healthcare professionals are often unprepared in answering the patients' religious beliefs regarding the diseases" and "patients are faced with religious clichés and stigma that results because of religious beliefs and practices." (p. 1)

- "As community members listen to their religious leaders, healthcare organizations should take religious leaders on board while handling and managing the COVID19." (p. 3). In this context, the authors proposed "a collaborative model between religious communities and healthcare providers/policymakers to manage the COVID-19.” (p. 2)

- The author argued that "religious populations and communities may be especially likely to acquire and spread the coronavirus" based on recent media sources on religion and COVID-19 (p. 2230)

- The author argued that "Our central argument is that more religious populations may be especially resistant to public health recommendations during the coronavirus pandemic (e.g., social distancing and staying at home) because they hold more negative views of science and scientists and strong religious beliefs concerning the pandemic itself." (p. 2230)

- The study found that in the early weeks of the pandemic, more religious states tend to exhibit higher average mobility scores, slower average declines in mobility and religious states were more resistant to stay-at-home orders. Hence, these findings "seem to confirm the suspicion that religious populations and communities may be especially likely to acquire and spread the coronavirus." (p. 2240)

- The author stressed that "we need to begin to think about ways of overcoming religious cultural barriers to critical pandemic responses. Potential strategies or interventions must systematically address obstacles related to the mistrust of science, religious authority, and religious liberty." (p. 2240) 


\begin{tabular}{llll}
\hline $\begin{array}{l}\text { Author and } \\
\text { publication year }\end{array}$ & Key interest & $\begin{array}{l}\text { Reported role of } \\
\text { religion in COVID- } \\
19\end{array}$ & Summary of the findings \\
& &
\end{tabular}

\begin{tabular}{ccc}
\hline $\begin{array}{c}\text { Hong and Handal } \\
(2020)\end{array}$ & $\begin{array}{c}\text { Institutional } \\
\text { collabora- } \\
\text { tion between }\end{array}$ & $\begin{array}{c}\text { Mitigation and } \\
\text { Adaptation }\end{array}$ \\
& Religion, & \\
& science, and & \\
& government &
\end{tabular}

- "Religion, science, and government have been institutions throughout the ages that have helped us deal with fears and threats like SARS-CoV-2. However, reliance on any one of these institutions exclusively has limitations and therefore are sources of disappointments." (p. 3)

- "From a broader perspective, even compliance with sheltering at home and social distancing can be seen as a religious response to the pandemic by not endangering others. For Christians, the principle of being your "brother's keeper" and for Jews, the message of Tikkun Olam (Cooper 2013) requires them to do acts of kindness "to heal a broken world." These statues are an embracement of religious values and devotion that support government requests during this pandemic." (p. 4)

- The author highlighted that "Science, religion, and government each provide ways to cope with this worldwide pandemic, but they can exercise a much greater impact if they operate in unison for the common good and well-being of all." (p. 5)

Iqbal et al. Religious cliché Mitigation (2020)

Jaja et al. (2020) Religious gath- Spread erings

- "The prevailing belief of life and death being controlled by the Almighty ${ }^{4}$ is also becoming a religious stigma in adopting precautionary measures." (p. 278)

- "Some Islamic faith believers did not follow the recommended precautions against COVID-19. ${ }^{2}$ On being questioned, it has been quoted that, 'Allah is sufficient for us; and what an excellent guardian He is. ${ }^{3}$ “(p. 278)

- "Combining and consuming water and sacred soil found at the grave of Maronite monk Mar Charbel (Mount Lebanon) is also practised against COVID-19." (p. 278)

- The author argued that engaging religious leaders is important to solve such religious cliché in the face of pandemic and this will help to overcome barriers for physicians in the optimal management of COVID-19

- "To date, over $80 \%$ of the Free State COVID emanated from this single religious event leading to the infection of over 80 persons and the further tracing of 1600 people who may have been exposed to the virus." (p. 1078)

- The authors argued that "religious and cultural activities of any form must be restricted at this time." (p. 1078) 


\begin{tabular}{|c|c|c|c|}
\hline $\begin{array}{l}\text { Author and } \\
\text { publication year }\end{array}$ & Key interest & $\begin{array}{l}\text { Reported role of } \\
\text { religion in COVID- } \\
19\end{array}$ & Summary of the findings \\
\hline Kang (2020) & $\begin{array}{l}\text { Religious gath- } \\
\text { erings }\end{array}$ & Spread & $\begin{array}{l}\text { - The Korean government, based on the } \\
\text { church member registry of } 244743 \\
\text { believers it acquired from the Shincheonji } \\
\text { authorities, analyzed connections among } \\
\text { the church members and found } 4212 \\
\text { confirmed COVID-19 cases by March } 2 \text {, } \\
2020 \text {. According to the analysis, } 93 \% \text { of } \\
\text { the confirmed cases were related to the } \\
\text { Shincheonji Church. [5]". (p. 169) } \\
\text { "Although religious services conducted in } \\
\text { crowded spaces like churches and temples } \\
\text { are vulnerable to infections, no specific } \\
\text { prevention guides have been issued by the } \\
\text { government." (p. 169) } \\
\text { "The temporary conclusion of this study } \\
\text { based on limited epidemiological data } \\
\text { and the currently available information on } \\
\text { confirmed cases is that group meetings and } \\
\text { religious services lead to massive infec- } \\
\text { tions of COVID-19. When a new infec- } \\
\text { tious disease is spreading, the government } \\
\text { should sharply curtail group gatherings } \\
\text { and religious events." (p. 170) }\end{array}$ \\
\hline
\end{tabular}




\begin{tabular}{llll}
\hline $\begin{array}{l}\text { Author and } \\
\text { publication year }\end{array}$ & Key interest & $\begin{array}{l}\text { Reported role of } \\
\text { religion in COVID- } \\
19\end{array}$ & Summary of the findings \\
& &
\end{tabular}

\begin{tabular}{|c|c|c|}
\hline Kim et al. (2020) & $\begin{array}{l}\text { Delay in } \\
\text { confirming } \\
\text { COVID-19 } \\
\text { cases related } \\
\text { to religious } \\
\text { group }\end{array}$ & $\begin{array}{l}\text { Spread and mitiga- } \\
\text { tion }\end{array}$ \\
\hline
\end{tabular}

- "In the secretive Shincheonji religious group, it is believed that the group's founder and leader can interpret the secret metaphors in the Holy Bible [6]. The members of the group believe that their spirit and bodies are immortal [7]. This belief may have led to their behaviour of not approaching public health authorities when they had COVID-19-related symptoms (e.g., fever or cough) and to their uncooperative attitude towards epidemiological investigations [8]. This is likely to have contributed to the delayed confirmation of cases, despite the massive nationwide public health campaign regarding COVID-19 that was implemented in early February 2020. [...] Therefore, this delay may have resulted in the broad spread of COVID-19 related to the Shincheonji religious group." (p. 166)

- "In response to the surge of cases of COVID-19 related to the Shincheonji religious group, the Korean National Assembly approved the Corona Three Act on February 26, 2020 [14]. This act encoded revisions of the Korean laws on infection prevention, quarantine, and medicine; specifically, the regulations regarding cases of infectious diseases were revised to mandate testing and quarantining of individuals suspected of having COVID-19 by national law. The enactment of the Corona Three Act was a significant event in Korea in that it was the first pan-governmental measure to prevent the spread of infectious diseases." (p. 166)

$\begin{array}{ll}\text { Koenig (2020b) } \quad \begin{array}{l}\text { Protecting reli- Adaptation } \\ \text { gious older } \\ \text { adults }\end{array} & \end{array}$

- The author made seven recommendations to help older adults to protect themselves and cope with difficulties during the COVID-19 pandemic: "(1) spend time developing a deeper religious faith; (2) stay physically healthy (e.g., to care for the "temple of Holy Spirit" follow by the Christian tradition); (3) care for your neighbour emphasized by Jesus, Moses, the Prophet Mohammad, the Buddha, Hindu sages, and other greater religious figures); (4) care for neighbour by meeting emotional needs; (5) care for neighbour by meeting physical needs; (6) follow by social distancing guidelines; and (7) taking advantage of technology (e.g., social and spiritual hugs and handshakes)" (p. 1-3) 


\begin{tabular}{llll}
\hline $\begin{array}{l}\text { Author and } \\
\text { publication year }\end{array}$ & Key interest & $\begin{array}{l}\text { Reported role of } \\
\text { religion in COVID- } \\
19\end{array}$ & Summary of the findings \\
& &
\end{tabular}

\begin{tabular}{lll}
\hline Koenig (2020a) & $\begin{array}{c}\text { Developing } \\
\text { spiritual }\end{array}$ \\
& resilience &
\end{tabular}

$\begin{array}{lll}\text { Lan et al. (2020) } & \begin{array}{c}\text { Religious } \\ \text { professionals } \\ \text { as contribu- } \\ \text { tors to local } \\ \text { transmission }\end{array} & \\ & & \\ & \begin{array}{c}\text { Negative reli- } \\ \text { gious coping }\end{array} & \text { Maladaptive coping } \\ \text { Lee (2020) } & \end{array}$

Lee et al. (2020) Negative religious coping

Levin (2020)

Institutional Adaptation
collaboration
between reli-
gion, health
care

- The author made six recommendations "for those who want to remain healthy and resilient-mentally, physically and spiritually-during this anxious time of the coronavirus pandemic: (1) Deepen Your Religious Faith; (2) Love Thy Neighbor as Thyself; (3) Use Technology; (4) Love and Care for Neighbor in Practical Ways;

(5) Don't Be Reckless; (6) Pay Attention to Physical Health." (p. 2-7)

- The study identified "the occupations at higher risk of COVID-19 transmission" and demonstrated that religious professionals were one of the "most common occupations in both early and late transmission periods." (p. 5)

- The study explored the association between COVID-19 related anxiety and negative religious coping which was measured by the item, "After thinking about the coronavirus, I wonder if God was angry with or had abandoned some people"

- The author found out that Coronavirus Anxiety Scale scores were strongly and positively associated with negative religious coping $(\mathrm{p}<0.001)$

Maladaptive coping $\bullet$ The study re-evaluated the Coronavirus Anxiety Scale and supported "these expectations with Coronavirus Anxiety Scale score being positively correlated with [...] negative religious coping. $(\mathrm{p}<0.001)$ )" (p. 6)

- The author asked religious institutions to be cooperative to the national health care "Religion, in general, and religious institutions, more specifically, can contribute to the national health care response effort and is doing so, although perhaps invisibly to much of the public."' (p. 8)

- The author posed a question, "When the postmortems are written, will this outbreak be viewed as a case study in religious hatred, persecution, violence, and general stupidity, or as an exemplar of faith-based cooperation and communal solidarity?" (Levin, 2020).” (p. 10) 


\begin{tabular}{lll}
\hline $\begin{array}{l}\text { Author and } \\
\text { publication year }\end{array}$ & Key interest & $\begin{array}{l}\text { Reported role of } \\
\text { religion in COVID- } \\
19\end{array}$
\end{tabular}

\begin{tabular}{lll}
\hline Lorea (2020) & $\begin{array}{l}\text { Return of } \\
\text { religion and } \\
\text { spirituality }\end{array}$ & Mistrust \\
\end{tabular}

Mat et al. (2020) Religious gath- Spread ering

McCloskey et al., Mass gather- Mitigation (2020a) ings 


\begin{tabular}{llll}
\hline $\begin{array}{l}\text { Author and } \\
\text { publication year }\end{array}$ & Key interest & $\begin{array}{l}\text { Reported role of } \\
\text { religion in COVID- } \\
19\end{array}$ & Summary of the findings \\
& &
\end{tabular}

\begin{tabular}{ccc}
\hline $\begin{array}{c}\text { McCloskey et al., } \\
\text { (2020b) }\end{array}$ & $\begin{array}{c}\text { Mass gather- } \\
\text { ings }\end{array}$ & Mitigation
\end{tabular}

McLaughlin

Memish et al. (2020)

\section{Modell and Kar- dia (2020)}

\section{Religious \\ reactions to \\ COVID-19}

Mass gather-
ings

\section{Report on how various reli- gions reacted to COVID-19}

Mitigation
- The authors emphasized that their main argument in McCloskey et al., 2020b: "all mass gatherings to be considered in context, including the prevailing advice on physical distancing and movement restrictions." (p. 1256)

- The authors argued that "we must look to the future. Whatever the course of the COVID-19 pandemic, countries, individually and collectively, will reach a point when they want to start removing restrictions and rebuild communities and economies. This will include decisions on re-starting mass gatherings. These decisions will need to be carefully reviewed and phased to ensure that the COVID-19 pandemic is not reignited; here, we advocate our risk-based approach as a sensible and rational way forward to consider those decisions." (p. 1256)

- The author provided "an overview of early-stage reactions by individuals and organizations affiliated with Buddhism, Shinto, New Religions, and other religious traditions in Japan.” (p. 1)

- The authors responded to McCloskey et al., 2020a

- As opposed to McCloskey et al. who recommended "to consider the effects of MG cancellations on the future wellbeing of communities through economic recession or job losses, as well as through the spread, or otherwise, of COVID-19." (McCloskey et al., 2020a, p. 1098), the authors argued that "there is hardly any lee way for choice." (p. 1192)

- The authors described that "when governments and societal and economic systems are unanimously intensifying efforts toward the economically and personally challenging concept of social distancing, any call to consider mass gatherings sends a diametrically opposing and confusing message to the public." (p. 1192)

- The authors explored the effort of religious community-based organizations including church-based health programs, providing hope and social services and religious faiths at the time of COVID-19 pandemic in Detroit, USA 


\begin{tabular}{llll}
\hline $\begin{array}{l}\text { Author and } \\
\text { publication year }\end{array}$ & Key interest & $\begin{array}{l}\text { Reported role of } \\
\text { religion in COVID- } \\
19\end{array}$ & Summary of the findings \\
& &
\end{tabular}

\begin{tabular}{ll}
\hline Muurlink and & Religious cloth- \\
Taylor-Robin- & Mitigation \\
son (2020) &
\end{tabular}

Nahandi et al.

(2020)

Peteet (2020)

\author{
Supporting reli- Adaptation \\ gious medical \\ professionals
}

- The author argued that "cultural factors may impact on the gender balance of reported COVID-19 infection prevalence in systematic ways, particularly in conservative societies whether religious or secular, around the world." (p. 2)

- The authors provided an example of Muslim culture where "wearing a burka or niqab, providing full or particle coverage of the face, respectively, is relatively common in public, touching of mouth, nose and eyes by females is correspondingly restricted." (p. 1)

- "Medical professionals working in the Islamic Republic of Iran are facing even more challenges compared to their colleagues in other countries when it comes to social support. [...] cultural and religious gatherings in the Islamic Republic of Iran might increase the risk of the spread of communicable diseases." (p. 497)

- "When considering the social restrictions imposed as a result of the efficiency of COVID19 transmission, virtual social networking might be the best replacement for traditional face-to-face psychological interventions." (p. 497)

- Even though there are some mental health care for health professionals, the authors called for revised and focused guidelines for them

- "Existential concerns raised by the pandemic suggest the importance of religious resources, as seen in research into the experience of patients dealing with advanced cancer." (p. 1)

- "Anxiety caused by COVID-19 calls for optimal self-case and accessible mental health services, but also for serious attention to how we can pursue Peace (Shalom, Salaam)." (p. 2) 


\begin{tabular}{llll}
\hline $\begin{array}{l}\text { Author and } \\
\text { publication year }\end{array}$ & Key interest & $\begin{array}{l}\text { Reported role of } \\
\text { religion in COVID- } \\
19\end{array}$ & Summary of the findings \\
& &
\end{tabular}

\begin{tabular}{cc}
\hline Prime et al. & Keeping family \\
$(2020)$ & Adaptation \\
& with religion
\end{tabular}

\section{Quadri (2020) Religious con- Mitigation gregations}

Safdar and Yas$\min (2020)$
Religious strug- Revealing reli-

gles during

COVID-19 giously inspired dominant patriarchal social behaviours
- The authors argued that "The COVID-19 pandemic poses an acute threat to the wellbeing of children and families due to challenges related to social disruption such as financial insecurity, caregiving burden, and confinement-related stress (e.g., crowding, changes to structure, and routine)." (p. 1) and "It is critical to consider the cultural, religious, and other sociological sources of variation in family beliefs (e.g., immigration and refugee history; Weine et al., 2006), given their undeniable role in processes of family resilience (Saltzman, Pynoos, Lester, Layne, \& Beardslee, 2013)." (p. 9)

- The authors also argued that family relationships/beliefs "will provide children with connection and growth during these emotionally difficult times, helping them to not only cope but thrive alongside their family members"

- The author described how religious congregations spread COVID-19 cases in various countries including Iran, Malaysia, Pakistan, India, South Korea, Israel, etc

- The author argued that "prompt responses such as suspension of communal gatherings must be promulgated to ensure social distancing." (p. 220)

- The authors explored "how the lockdown/ containment measures taken by the government during the COVID-19 pandemic have threatened educated Muslim women's negotiated identity regarding wifehood and motherhood in urban Pakistan and how they struggle to reposition to reconstruct it." (p. 1)

- "This study indicates that if educated urban women feel the social pressure to step back to their traditional patriarchal roles while bearing domestic violence as well, the situation of those living in remote/rural areas or less empowered women could be much worse." (p. 10) 


\begin{tabular}{llll}
\hline $\begin{array}{l}\text { Author and } \\
\text { publication year }\end{array}$ & Key interest & $\begin{array}{l}\text { Reported role of } \\
\text { religion in COVID- } \\
19\end{array}$ &
\end{tabular}

\begin{tabular}{ccc}
\hline Shah et al. (2020) & $\begin{array}{c}\text { Religious } \\
\text { norms }\end{array}$ & $\begin{array}{c}\text { Misinformation } \\
\text { Racial segregation }\end{array}$
\end{tabular}

- The author discussed how Social Determinants of Health affected people during COVID-19 and argued that "Higher rates among black communities not only can be attributed to initial misinformation of the outbreak but are also suggestive of more deep-rooted issues such as deteriorating SES, nonconformity to preventive practices when they contradict social or religious norms, and a long-standing distrust toward health care institutions." (p. 317)

$\begin{array}{cc}\text { Tarimo and Wu } & \begin{array}{c}\text { Religious gath- Mitigation } \\ \text { erings }\end{array}\end{array}$

Thompkins et al. Message to Adaptation (2020) pastors

$\begin{array}{ccc}\text { Tootee and Lari- } & \text { Ramadan dur- } \\ \text { jani (2020) } & \text { Adaptation } \\ & 19\end{array}$
- The authors explored the first imported COVID-19 case to Tanzania and served several recommendations to mitigate potential spread

- "This letter calls upon the government of Tanzania to immediately suspend not only schools and colleges as it has been successfully done but also all religious and any other social gatherings." (p. 2)

- "A serios of 15-min videos were produced to provide resources to pastors in AfricanAmerican communities to aid them in conveying accurate public and mental health information about COVID-19.” (p. 455)

- "The pastors' video presentations not only provided accurate information about COVID-19 but described their evolving role as advocates. Because the two public health official video contributors were church members, they were able to effectively blend spiritual with public health messaging." (p. 456)

- "This time, arguably for the first time in the modern era, jurisprudence scholars, academics, and medical practitioners all seem perplexed as to whether temporary starvation and dehydration might increase the risk of contracting the circulating corona virus." (p. 2)

- The authors argued that "the ultimate decision in this regard would be made by each individual person (according to the fatwas) based on the recommendations of the physician in charge." (p. 3) 


\begin{tabular}{llll}
\hline $\begin{array}{l}\text { Author and } \\
\text { publication year }\end{array}$ & Key interest & $\begin{array}{l}\text { Reported role of } \\
\text { religion in COVID- } \\
19\end{array}$ & Summary of the findings \\
\hline
\end{tabular}

\begin{tabular}{|c|c|c|}
\hline $\begin{array}{l}\text { Umucu and Lee } \\
\text { (2020) }\end{array}$ & $\begin{array}{c}\text { Religion as } \\
\text { a coping } \\
\text { strategy }\end{array}$ & Adaptation \\
\hline $\begin{array}{l}\text { Waitzberg et al. } \\
(2020)\end{array}$ & $\begin{array}{l}\text { Tailored } \\
\text { measures } \\
\text { for minority } \\
\text { populations } \\
\text { (ultra-Ortho- } \\
\text { dox Jewish } \\
\text { and Arab } \\
\text { population) }\end{array}$ & $\begin{array}{c}\text { Mitigation an } \\
\text { adaptation }\end{array}$ \\
\hline
\end{tabular}

$\begin{array}{ccc}\text { Waqar and } & \text { Ramadan dur- } \\ \text { Ghouri (2020) } & \text { Adaptation } \\ & 19\end{array}$

- The authors examined "(a) perceived
stress related to COVID-19, (b) coping
mechanisms related to COVID-19, and (c) the relationship between coping strategies related to COVID-19 and well-being in people with self-reported disabilities and chronic conditions." (p. 2)

- The study has demonstrated that COVID19-related perceived stress was positively associated with coping strategies including religion $(\mathrm{p}<0.01)$ and religion is positively associated with participants' well-being $(\mathrm{p}<0.01)$

- The authors argued that minority groups in Israel including ultra-Orthodox Jewish community and the Arab population have been encountered "greater challenges in adopting physical distancing measures", hence more vulnerable to the COVID-19. (p. 1)

- In this context, the authors argued that "these populations require specially targeted and tailored responses that take into account their situation with regard to access to healthcare, living and working conditions, and ability to maintain physical distancing, so as not to become foci of infection that will ultimately affect all sectors of society." (p. 5)

- The authors outlined some "practical tips for clinicians on how to counsel and manage Muslim patients who are fasting in Ramadan, with some consideration for the context of COVID-19." (p. 1)

- The author highlighted that "some Muslim patients have a very strong motivation to fast in Ramadan, even if they have significant comorbidities such as cancer or advanced organ disease. Ignoring or being indifferent to this may lead to patients and their families losing trust in their clinicians, and possibly coming to harm from self-management and not seeking further counsel when needing advice." (p. 3) 


\begin{tabular}{llll}
\hline $\begin{array}{l}\text { Author and } \\
\text { publication year }\end{array}$ & Key interest & $\begin{array}{l}\text { Reported role of } \\
\text { religion in COVID- } \\
19\end{array}$ & Summary of the findings \\
\hline
\end{tabular}

\begin{tabular}{|c|c|c|c|}
\hline $\begin{array}{l}\text { Weinberger- } \\
\text { Litman et al. } \\
(2020)\end{array}$ & $\begin{array}{l}\text { Role of reli- } \\
\text { gious institu- } \\
\text { tions, stigma } \\
\text { towards } \\
\text { religion in } \\
\text { the time of } \\
\text { COVID-19 }\end{array}$ & Mitigation & $\begin{array}{l}\text { - The study explored "the ways in which the } \\
\text { Modern Orthodox Jewish community, "as } \\
\text { both the first one in the USA with known } \\
\text { widespread transmission and one with a } \\
\text { highly visible religious identity, experi- } \\
\text { ences stigma in relation to COVID-19 and } \\
\text { the extent to which that impact distress/ } \\
\text { anxiety." The study also examined "the } \\
\text { ways in which the clarity of health infor- } \\
\text { mation is related to distress/anxiety and } \\
\text { how religious institutions play a role in } \\
\text { conveying COVID-19-related information, } \\
\text { which in turn may mitigate the psychologi- } \\
\text { cal impacts of quarantine." (p. } 2271 \text { ) } \\
\text { The results have shown that 50.3\% of par- } \\
\text { ticipants were "anticipating stigma or actu- } \\
\text { ally experiencing stigma due to the asso- } \\
\text { ciation of their religious community with } \\
\text { the pandemic." The study also showed } \\
\text { that, "only } 20 \% \text { of the current sample } \\
\text { found the information they received from } \\
\text { local agencies to be adequate, while more } \\
\text { than half (60\%) reported that they found } \\
\text { the clarity of information either completely } \\
\text { inadequate or with significant gaps." [...] } \\
\text { "more participants reported that they } \\
\text { completely trusted information provided } \\
\text { by their local community institutions than } \\
\text { from any other information source," (p. } \\
2278-9 \text { ) } \\
\text { The authors highlighted that "religious } \\
\text { organizations should be viewed as valu- } \\
\text { able community partners in disseminating } \\
\text { and supporting public health messag- } \\
\text { ing," [...] "as misinformation regarding } \\
\text { COVID-19 and myriad other health-related } \\
\text { issues abound, religious leaders have an } \\
\text { opportunity and responsibility to provide } \\
\text { scientifically informed health education." } \\
\text { (p. } 2280 \text { ) }\end{array}$ \\
\hline
\end{tabular}




\begin{tabular}{llll}
\hline $\begin{array}{l}\text { Author and } \\
\text { publication year }\end{array}$ & Key interest & $\begin{array}{l}\text { Reported role of } \\
\text { religion in COVID- } \\
19\end{array}$ &
\end{tabular}

\begin{tabular}{ll}
\hline Wildman et al. & $\begin{array}{r}\text { Role of religion } \\
\text { in the time of } \\
\text { COVID-19 }\end{array}$ \\
& $\begin{array}{l}\text { Spread and mitiga- } \\
\text { tion }\end{array}$
\end{tabular}

- The authors explored "the role of religious practices in spreading SARS-CooV-2, the virus responsible for the COVID-19 pandemic." (p. 115)

- The authors asked a question; "Collective worship is an effective mechanism for accelerating its spread. Is religion, then, complicit in the most daunting global health crisis of our time?" (p. 116) and argued that "The behaviors of problematic churches are attracting the media's attention, but in many regions of the world religious communities are more beneficial than harmful." (p. 116)

$\begin{array}{cl}\text { Wong et al. } & \text { Religious gath- Mitigation } \\ \text { (2020) } & \text { ering }\end{array}$

$\begin{array}{cc}\text { Yezli and Khan } & \begin{array}{c}\text { Religious gath- Mitigation } \\ \text { ering }\end{array}\end{array}$
Yezli and Khan Religious gath- Mitigation (2020b)

- The authors explored asymptomatic transmission of COVID-19 from mass gatherings and highlighted their argument for "widespread testing at mass gatherings in areas of known community transmission." (p. 2)

- The authors stated that "Recently, numerous COVID-19 cases were linked to places of worship and religious gatherings." (p. 1)

- The authors recommended for religious services to be suspended- "It is then time to also temporarily close places of worship and suspend religious gatherings. [...] "for such measures to be effective and not be counterproductive, risk communication and educating the public regarding the reasoning behind and aim of such actions are crucial. The latter should be done through both official authorities and religious and community leaders and organizations, as to avoid resentment and rebellion against these measures and prevent religious gatherings moving from the official places of worship to makeshift indoor or outdoor locations that could present a similar or greater risk for COVID-19 transmission." (p. 1)

- The authors stated that even though religion is a major pillar of Saudi society, "the decision on the 2020 Hajj will be an informed weighing between the risk of the pilgrimage going ahead and the consequence of it being suspended. The priority will be protecting the public and ensuring global health security." (p. 3) 
Acknowledgements The Authors thank Yvonne Supeene for providing editorial feedback on the final manuscript.

Author contributions EL and MSX conceived and designed the study. EL conducted database searches and imported data to screening software. EL and HL screened and extracted the data. EL and MSX wrote the first draft of Introduction and Methods. ML led data interpretation and the writing of the final manuscript. All authors provided feedback and approved the final manuscript.

Funding No funding was received to assist with the preparation of this study.

Availability of data and material The review protocol was registered on PROSPERO (Record ID: CRD42020182884), the international prospective register of systematic reviews (https://www.crd.york. ac.uk/prospero/display_record.php?RecordID=182884).

\section{Declarations}

Conflict of interest The authors have no conflicts of interest.

\section{References}

Agley, J. (2020). Assessing changes in US public trust in science amid the COVID-19 pandemic. Public Health, 183, 122-125. https://doi.org/10.1016/j.puhe.2020.05.004

Ahmed, Q. A., \& Memish, Z. A. (2020). The cancellation of mass gatherings (MGs)? Decision making in the time of COVID-19. Travel Medicine and Infectious Disease, 34, 1-4. https://doi.org/10.1016/j. tmaid.2020.101631

Al-Rousan, N., \& Al-Najjar, H. (2020). Is visiting Qom spread CoVID-19 epidemic in the Middle East? European Review for Medical and Pharmacological Sciences, 24(10), 5813-5818. https://doi.org/ 10.26355/eurrev_202005_21376

Ali, I., \& Alharbi, O. M. L. (2020). COVID-19: Disease, management, treatment, and social impact. Science of the Total Environment, 728, 1-6. https://doi.org/10.1016/j.scitotenv.2020.138861

Alzoubi, H., Alnawaiseh, N., Al-Mnayyis, A., Abu-Lubad, M., Aqel, A., \& Al-Shagahin, H. (2020). Covid-19 - Knowledge, attitude and practice among medical and non-medical university students in Jordan. Journal of Pure and Applied Microbiology, 14(1), 17-24. https://doi.org/10.22207/JPAM. 14.1.04

Aromataris, E., \& Pearson, A. (2014). The systematic review: An overview. American Journal of Nursing, 114(3), 53-58. https://doi.org/10.1097/01.NAJ.0000444496.24228.2c

Atique, S., \& Itumalla, R. (2020). Hajj in the time of COVID-19. Infection, Disease and Health, 25, 219-221. https://doi.org/10.1016/j.idh.2020.04.001

Bell, B. P., Damon, I. K., Jernigan, D. B., Kenyon, T. A., Nichol, S. T., \& OConnor JP, Tappero JW, . (2016). Overview, control strategies, and lessons learned in the CDC response to the 2014-2016 Ebola epidemic. MMWR Supplements, 65(3), 4-11. https://doi.org/10.15585/mmwr.su6503a2

Blevins, J. B., Jalloh, M. F., \& Robinson, D. A. (2019). Faith and global health practice in Ebola and HIV emergencies. American Journal of Public Health, 109(3), 379-384. https://doi.org/10.2105/AJPH. 2018.304870

Capponi, G. (2020). Overlapping values: Religious and scientific conflicts during the COVID-19 crisis in Brazil. Social Anthropology, 28(2), 236-237. https://doi.org/10.1111/1469-8676.12795

Carey, L. B. (2020). COVID-19, Aged Care, Cancer, Medical Research and Mental Health. Journal of Religion and Health, 59(6), 2667-2670. https://doi.org/10.1007/s10943-020-01127-z

Chirico, F., \& Nucera, G. (2020). An Italian experience of spirituality from the Coronavirus pandemic. Journal of Religion and Health, 59(5), 2193-2195. https://doi.org/10.1007/s10943-020-01036-1

Choi, H., Cho, W., Kim, M. H., \& Hur, J. Y. (2020). Public health emergency and crisis management: Case study of SARS-CoV-2 outbreak. International Journal of Environmental Research and Public Health, 17(11), 3984. https://doi.org/10.3390/ijerph17113984 
Chukwuorji, J. B. C., \& Iorfa, S. K. (2020). Commentary on the Coronavirus pandemic: Nigeria. Psychological Trauma: Theory, Research, Practice, and Policy, 12(S1), S188. https://doi.org/10.1037/tra00 00786

Crubézy, E., \& Telmon, N. (2020). Pandemic-related excess mortality (COVID-19), public health measures and funerary rituals. EClinicalMedicine. https://doi.org/10.1016/j.eclinm.2020.100358

Dalmida, S. G., Koenig, H. G., Holstad, M. M., \& Thomas, T. L. (2015). Religious and psychosocial covariates of health-related quality of life in people living with HIV/AIDS. HIV/AIDS Research and Treatment - Open Journal, 1(1), 1-15. https://doi.org/10.17140/hartoj-1-101

Ebrahim, S. H., \& Memish, Z. A. (2020a). Saudi Arabia's drastic measures to curb the COVID-19 outbreak: Temporary suspension of the Umrah pilgrimage. Journal of Travel Medicine, 27(3), 1-2. https://doi.org/10.1093/jtm/taaa029

Ebrahim, S. H., \& Memish, Z. (2020b). COVID-19 - the role of mass gatherings. Travel Medicine and Infectious Disease, 34, 1-3. https://doi.org/10.1016/j.tmaid.2020.101617

Escher, A. R. (2020). An ounce of prevention: Coronavirus (COVID-19) and mass gatherings. Cureus, 12(3), 12-14. https://doi.org/10.7759/cureus.7345

Fisher, K. A., Bloomstone, S. J., Walder, J., Crawford, S., Fouayzi, H., \& Mazor, K. M. (2020). Attitudes toward a potential SARS-CoV-2 vaccine: A survey of U.S. adults. Annals of Internal Medicine, 173(12), 964-973. https://doi.org/10.7326/m20-3569

Freeman, D., Waite, F., Rosebrock, L., Petit, A., Causier, C., East, A., \& Lambe, S. (2020). Coronavirus conspiracy beliefs, mistrust, and compliance with government guidelines in England. Psychological Medicine. https://doi.org/10.1017/S0033291720001890

Frei-Landau, R. (2020). "When the going gets tough, the tough get-creative": Israeli Jewish religious leaders find religiously innovative ways to preserve community members' sense of belonging and resilience during the COVID-19 pandemic. Psychological Trauma: Theory, Research, Practice, and Policy, 12(S1), S258. https://doi.org/10.1037/tra0000822

Galiatsatos, P., Monson, K., Oluyinka, M. J., Negro, D. R., Hughes, N., Maydan, D., Golden, S. H., Teague, P., \& Hale, W. D. (2020). Community calls: Lessons and insights gained from a medicalreligious community engagement during the COVID-19 pandemic. Journal of Religion and Health, 59(5), 2256-2262. https://doi.org/10.1007/s10943-020-01057-w

Gautret, P., Al-Tawfiq, J. A., \& Hoang, V. T. (2020). COVID 19: Will the 2020 Hajj pilgrimage and Tokyo Olympic Games be cancelled? Travel Medicine and Infectious Disease, 34, 19-21. https:// doi.org/10.1016/j.tmaid.2020.101622

Greene, T., Bloomfield, M. A. P., \& Billings, J. (2020). Psychological trauma and moral injury in religious leaders during COVID-19. Psychological Trauma: Theory, Research, Practice, and Policy. https://doi.org/10.1037/tra0000641

Ha, K. M. (2020). A lesson learned from the outbreak of COVID-19 in Korea. Indian Journal of Microbiology, 60(3), 396-397. https://doi.org/10.1007/s12088-020-00882-7

Hart, C. W., \& Koenig, H. G. (2020). Religion and health during the COVID-19 pandemic. Journal of Religion and Health, 59(3), 1141-1143. https://doi.org/10.1007/s10943-020-01042-3

Hashmi, F. K., Iqbal, Q., Haque, N., \& Saleem, F. (2020). Religious cliché and stigma: A brief response to overlooked barriers in COVID-19 management. Journal of Religion and Health, 59(6), 26972700. https://doi.org/10.1007/s10943-020-01063-y

Hill, T. D., Gonzalez, K., \& Burdette, A. M. (2020). The blood of christ compels them: State religiosity and state population mobility during the Coronavirus (COVID-19) pandemic. Journal of Religion and Health, 59(5), 2229-2242. https://doi.org/10.1007/s10943-020-01058-9

Hong, B. A., \& Handal, P. J. (2020). Science, religion, government, and SARS-CoV-2: A time for synergy. Journal of Religion and Health, 59(5), 2263-2268. https://doi.org/10.1007/s10943-020-01047-y

Idler, E. L. (2014). Religion as a social determinant of public health. Oxford: Oxford University Press.

Iqbal, Q., Tareen, A. M., \& Saleem, F. (2020). Religious cliché and COVID-19 management : A barrier for physicians. British Journal of General Practice, 70(697), 278-278. https://doi.org/10.3399/ bjgp20X709961

Jaja, I. F., Anyanwu, M. U., \& Iwu Jaja, C. J. (2020). Social distancing: How religion, culture and burial ceremony undermine the effort to curb COVID-19 in South Africa. Emerging Microbes and Infections, 9(1), 1077-1079. https://doi.org/10.1080/22221751.2020.1769501

Jelowicki, A. (2020). Montreal's Jewish community feels targeted during coronavirus crisis. Global News. https://globalnews.ca/news/6775920/montreal-jewish-community-coronavirus-covid-19/. 
Kang, Y. J. (2020). Characteristics of the COVID-19 outbreak in Korea from the mass infection perspective. Journal of Preventive Medicine and Public Health, 53(3), 168-170. https://doi.org/10.3961/ JPMPH.20.072

Kawachi, I. (2020). Invited commentary: Religion as a social determinant of health. American Journal of Epidemiology, 189(12), 1461-1463. https://doi.org/10.1093/aje/kwz204

Kim, H. J., Hwang, H. S., Choi, Y. H., Song, H. Y., Park, J. S., Yun, C. Y., \& Ryu, S. (2020). The delay in confirming COVID-19 cases linked to a religious group in Korea. Journal of Preventive Medicine and Public Health, 53(3), 164-167. https://doi.org/10.3961/JPMPH.20.088

Koenig, H. G. (2020a). Maintaining health and well-being by putting faith into action during the COVID-19 pandemic. Journal of Religion and Health, 59(5), 2205-2214. https://doi.org/10.1007/ s10943-020-01035-2

Koenig, H. G. (2020b). Ways of protecting religious older adults from the consequences of COVID-19. American Journal of Geriatric Psychiatry, 28(7), 776-779. https://doi.org/10.1016/j.jagp.2020.04. 004

Ladaria Ferrer, L. (2020). Note on the morality of using some anti-Covid-19 vaccines. The Holy See website: https://www.vatican.va/roman_curia/congregations/cfaith/documents/rc_con_cfaith_doc_ 20201221_nota-vaccini-anticovid_en.html.

Lan, F. Y., Wei, C. F., Hsu, Y. T., Christiani, D. C., \& Kales, S. N. (2020). Work-related COVID-19 transmission in six Asian countries/areas: A follow-up study. PLOS ONE, 15(5), 1-11. https://doi.org/10. 1371/journal.pone.0233588

Larson, H. J., Jarrett, C., Eckersberger, E., Smith, D. M. D., \& Paterson, P. (2014). Understanding vaccine hesitancy around vaccines and vaccination from a global perspective: A systematic review of published literature, 2007-2012. Vaccine, 32(19), 2150-2159. https://doi.org/10.1016/j.vaccine.2014. 01.081

Lee, S. A. (2020). Coronavirus anxiety scale: A brief mental health screener for COVID-19 related anxiety. Death Studies, 44(7), 393-401. https://doi.org/10.1080/07481187.2020.1748481

Lee, S. A., Mathis, A. A., Jobe, M. C., \& Pappalardo, E. A. (2020). Clinically significant fear and anxiety of COVID-19: A psychometric examination of the Coronavirus anxiety scale. Psychiatry Research, 290, 113112. https://doi.org/10.1016/j.psychres.2020.113112

Levin, J. (2020). The faith community and the SARS-CoV-2 outbreak: Part of the problem or part of the solution? Journal of Religion and Health, 59(5), 2215-2228. https://doi.org/10.1007/ s10943-020-01048-x

Lorea, C. E. (2020). Religious returns, ritual changes and divinations on COVID-19. Social Anthropology, 28(2), 307-308. https://doi.org/10.1111/1469-8676.12865

MacDonald, N. E., Eskola, J., Liang, X., Chaudhuri, M., Dube, E., Gellin, B., \& Schuster, M. (2015). Vaccine hesitancy: Definition, scope and determinants. Vaccine, 33(34), 4161-4164. https://doi.org/ 10.1016/j.vaccine.2015.04.036

Magadmi, R. M., \& Kamel, F. O. (2020). Beliefs and barriers associated with COVID-19 vaccination among the general population in Saudi Arabia. Research Square. https://doi.org/10.21203/rs.3.rs48955/v1

Mat, N. F. C., Edinur, H. A., Razab, M. K. A. A., \& Safuan, S. (2020). A single mass gathering resulted in massive transmission of COVID-19 infections in Malaysia with further international spread. Journal of Travel Medicine, 27(3), 1-4. https://doi.org/10.1093/jtm/taaa059

McCloskey, B., Zumla, A., Ippolito, G., Blumberg, L., Arbon, P., Cicero, A., \& Borodina, M. (2020a). Mass gathering events and reducing further global spread of COVID-19: A political and public health dilemma. The Lancet, 395(10230), 1096-1099. https://doi.org/10.1016/S0140-6736(20) 30681-4

McCloskey, B., Zumla, A., Lim, P. L., Endericks, T., Arbon, P., Cicero, A., \& Borodina, M. (2020b). A risk-based approach is best for decision making on holding mass gathering events. The Lancet, 395(10232), 1256-1257. https://doi.org/10.1016/S0140-6736(20)30794-7

McLaughlin, L. (2020). Japanese religious responses to COVID-19: A preliminary report. 18(9).

Memish, Z. A., Ahmed, Q. A., Schlagenhauf, P., Doumbia, S., \& Khan, A. (2020). No time for dilemma: Mass gatherings must be suspended. The Lancet, 395, 1191-1192. https://doi.org/10.1016/S01406736(20)30754-6

Modell, S. M., \& Kardia, S. L. R. (2020). Religion as a health promoter during the 2019/2020 COVID outbreak: View from Detroit. Journal of Religion and Health, 59(5), 2243-2255. https://doi.org/10. 1007/s10943-020-01052-1 
Muurlink, O. T., \& Taylor-Robinson, A. W. (2020). COVID-19: Cultural predictors of gender differences in global prevalence patterns. Frontiers in Public Health, 8, 174. https://doi.org/10.1002/cb.1379

Nahandi, M. Z., Shahrokhi, H., Farhang, S., \& Somi, M. H. (2020). Virtual social networks and mental health intervention for medical staff during the COVID-19 outbreak in the islamic Republic of Iran. Eastern Mediterranean Health Journal, 26(5), 497-498. https://doi.org/10.26719/2020.26.5.497

Page, M. J., McKenzie, J. E., Bossuyt, P. M., Boutron, I., Hoffmann, T. C., Mulrow, C. D., \& Moher, D. (2021). The PRISMA 2020 statement: An updated guideline for reporting systematic reviews. The BMJ. https://doi.org/10.1136/bmj.n71

Pargament, K., McCarthy, S., Shah, P., Ano, G., Tarakeshwar, N., Wachholtz, A., \& Duggan, J. (2004). Religion and HIV: A review of the literature and clinical implications. Southern Medical Journal, 97(12), 1201-1210.

Peteet, J. R. (2020). COVID-19 anxiety. Journal of Religion and Health, 59(5), 2203-2204. https://doi. org/10.1007/s10943-020-01041-4

Prime, H., Wade, M., \& Browne, D. T. (2020). Risk and resilience in family well-being during the COVID-19 pandemic. American Psychologist, 75(5), 631-643. https://doi.org/10.1037/amp0000660

Public Health Agency of Canada. (2016). Social determinants of health. https://cbpp-pcpe.phac-aspc.gc. $\mathrm{ca} /$ public-health-topics/social-determinants-of-health/

Pugh, S. A. (2010). Examining the interface between HIV/AIDS, religion and gender in Sub-Saharan Africa. Canadian Journal of African Studies / Revue Canadienne Des Études Africaines, 44(3), 624-643. https://doi.org/10.1080/00083968.2010.9707548

Quadri, S. A. (2020). COVID-19 and religious congregations: Implications for spread of novel pathogens. International Journal of Infectious Diseases, 96, 219-221. https://doi.org/10.1016/j.ijid.2020. 05.007

Rahim, Z. (2020). In the latest sign of Covid-19-related racism, Muslims are being blamed for England's coronavirus outbreaks. CNN. https://www.cnn.com/2020/08/06/europe/muslims-coronavirus-engla nd-islamophobia-gbr-intl/index.html

Ransome, Y. (2020). Religion, spirituality, and health: New considerations for epidemiology. American Journal of Epidemiology, 189(8), 755-758. https://doi.org/10.1093/aje/kwaa022

Reichler, M. R., Bangura, J., Bruden, D., Keimbe, C., Duffy, N., Thomas, H., \& Hersey, S. (2018). Household transmission of ebola virus: Risks and preventive factors, Freetown, Sierra Leone, 2015. Journal of Infectious Diseases, 218(5), 757-767. https://doi.org/10.1093/infdis/jiy204

Safdar, M., \& Yasmin, M. (2020). COVID-19: A threat to educated Muslim women's negotiated identity in Pakistan. Gender, Work and Organization, 27(5), 683-694. https://doi.org/10.1111/gwao.12457

Schuster, M. A., Stein, B. D., Jaycox, L. H., Collins, R. L., Marshall, G. N., Elliott, M. N., \& Berry, S. H. (2001). A national survey of stress reactions after the September 11, 2001, terrorist attacks. New England Journal of Medicine, 345(20), 1507-1512. https://doi.org/10.1056/NEJM20011115345 2024

Shah, G. H., Shankar, P., Schwind, J. S., \& Sittaramane, V. (2020). The detrimental impact of the COVID-19 crisis on health equity and social determinants of health. Journal of Public Health Management and Practice, 26(4), 317-319. https://doi.org/10.1097/PHH.0000000000001200

Smith, C. (2019). Religion: What it is, how it works, and why it matters. Princeton: Princeton University Press.

Tarimo, C. S., \& Wu, J. (2020). The first confirmed case of COVID-19 in Tanzania: Recommendations based on lesson learned from China. Tropical Medicine and Health, 48(1), 2. https://doi.org/10. 1186/s41182-020-00214-x

The British Board of Scholars and Imams. (2020). Top ten questions Imams \& scholars get asked about vaccines.

Thompkins, F., Goldblum, P., Lai, T., Hansell, T., Barclay, A., \& Brown, L. M. (2020). A culturally specific mental health and spirituality approach for african americans facing the COVID-19 pandemic. Psychological Trauma: Theory, Research, Practice, and Policy, 12(5), 455-456. https://doi.org/10. 1037/tra0000841

Tootee, A., \& Larijani, B. (2020). Ramadan fasting during Covid-19 pandemic. Journal of Diabetes and Metabolic Disorders, 19(1), 1-4. https://doi.org/10.1007/s40200-020-00534-z

U.S. President's Emergency Plan for AIDS Relief. (2015). Building on firm foundation: The 2015 consultation on strengthening partnerships between PEPFAR and faith-based organizations to build capacity for sustained responses to HIV/AIDS. In Washington, DC: U.S. Department of State. https://doi. org/10.4324/9781315453736-11 
Umucu, E., \& Lee, B. (2020). Examining the impact of COVID-19 on stress and coping strategies in individuals with disabilities and chronic conditions. Rehabilitation Psychology, 65(3), 193-198. https:// doi.org/10.1037/rep0000328

VanderWeele, T. J. (2017). Religion and health: A synthesis.

Waitzberg, R., Davidovitch, N., Leibner, G., Penn, N., \& Brammli-Greenberg, S. (2020). Israel's response to the COVID-19 pandemic: Tailoring measures for vulnerable cultural minority populations. International Journal for Equity in Health, 19(1), 7-11. https://doi.org/10.1186/s12939-020-01191-7

Wang, J., Jing, R., Lai, X., Zhang, H., Lyu, Y., Knoll, M. D., \& Fang, H. (2020). Acceptance of covid-19 vaccination during the covid-19 pandemic in china. Vaccines, 8(3), 1-14. https://doi.org/10.3390/ vaccines 8030482

Waqar, S., \& Ghouri, N. (2020). Managing ramadan queries in COVID-19. BJGP Open, 4(2), 2-5. https://doi.org/10.3399/BJGPOPEN20X101097

Weinberger-Litman, S. L., Litman, L., Rosen, Z., Rosmarin, D. H., \& Rosenzweig, C. (2020). A look at the first quarantined community in the USA: Response of religious communal organizations and implications for public health during the COVID-19 pandemic. Journal of Religion and Health, 59(5), 2269-2282. https://doi.org/10.1007/s10943-020-01064-x

Wildman, W. J., Bulbulia, J., Sosis, R., \& Schjoedt, U. (2020). Religion and the COVID-19 pandemic. Religion, Brain and Behavior, 10(2), 115-117. https://doi.org/10.1080/2153599X.2020.1749339

Wilson, E. (2020). Religious inequalities and the impact of Covid-19. Institute of Development Studies. https://www.ids.ac.uk/news/religious-inequalities-and-the-impact-of-covid-19/

Wong, J., Jamaludin, S. A., Alikhan, M. F., \& Chaw, L. (2020). Asymptomatic transmission of SARSCoV-2 and implications for mass gatherings. Influenza and Other Respiratory Viruses, 14(5), 596598. https://doi.org/10.1111/irv.12767

Yezli, S., \& Khan, A. (2020a). COVID-19 pandemic: It is time to temporarily close places of worship and to suspend religious gatherings. Journal of Travel Medicine. https://doi.org/10.1093/jtm/taaa065

Yezli, S., \& Khan, A. (2020b). COVID-19 social distancing in the Kingdom of Saudi Arabia: Bold measures in the face of political, economic, social and religious challenges. Travel Medicine and Infectious Disease, 37, 101692. https://doi.org/10.1016/j.tmaid.2020.101692

Publisher's Note Springer Nature remains neutral with regard to jurisdictional claims in published maps and institutional affiliations. 